\title{
Not out of the box: phylogeny of the broadly sampled Buxaceae
}

Running title: Phylogeny of Buxaceae

Alexey Shipunov ${ }^{1}$, Hye Ji Lee ${ }^{1}$, Jinhee Choi $^{1}$, Kyle Pay ${ }^{1}$, Sarah DeSpiegelaire ${ }^{1}$, Aaron Floden ${ }^{2}$

${ }^{1}$ Minot State University, Biology, 500 University Ave, Minot, ND

${ }^{2}$ Missouri Botanical Garden Herbarium, Monsanto Center, 4344 Shaw Blvd, St. Louis, MO 63110

\section{Acknowledgements}

Our research was supported by North Dakota INBRE and by the Department of Biology of Minot State

University. Some of the sequences are results of collaboration with the Barcoding of Life project. We are grateful to the curators of all herbaria provided us with samples, namely US, NY, HUH, MO, CAS, UC, JEPS, K, F, BRIT, B, BO, IBSC, MICH, MO, NY, PE, TI, SPF, SP, USM, PRE, NBG, SAM. AF thanks Dr. Schilling for his encouragement and allowance of taking on extracurricular projects into my many interests while working towards my Ph.D., Dr. Jose Panero for sending the duplicate specimens that instigated part of this project, Joe May and Veronica Brown at the UT Genomics Core, Kelly and Sue at Far Reaches Farm for an additional Sarcococca wallichii, Dr. P.D. González Gutiérrez for discussion of his thesis work of Neotropical Buxus, and Dr. T. Mitchell and B. Wynn-Jones for support in Vietnam. AS thanks Dr. Hidetoshi Nagamasu (University of Kyoto) and Ms. Chikako Hasekura (Tokyo University of Agriculture) for the help with Japanese plants, and Ekaterina Shipunova, Maxim Nuraliev (Moscow State University), Polina Volkova (Papanin Institute for Biology of Inland Waters, Russia), Maria Kuzmina (University of Guelph), and Subdirección Científica, Jardín Botánico de Bogotá José Celestino Mutis (Bogota, Colombia) for help with obtaining and sequencing samples.

\section{Abstract and keywords}


The Buxaceae constitute a morphologically diverse phylogenetic lineage of six genera, which includes about 140 species. The most well-known genera are Buxus, Sarcococca, and Pachysandra. Few species of woody Styloceras grow on mid-elevations in the Andes mountains region. Didymeles, with three species endemic to Madagascar, and the monotypic Haptanthus from Honduras, are the most unusual members of the group. The infra-familial classification of Buxaceae is controversial, and molecular data about many species, especially Old World, is still lacking. We used broad taxonomic sampling and molecular data from four chloroplast markers, and the nuclear ribosomal ITS to estimate their phylogeny. These data provide phylogenetic placements of 50 species and enabled better estimates of boundaries in Buxaceae. We described two subfamilies, two monotypic genera, two Buxus subgenera, and one new species of Didymeles from Madagascar.

Keywords: Buxaceae, Haptanthus, Didymeles, Buxus, Sarcococca, Pachysandra, Styloceras, phylogeny

\section{Introduction}

Within flowering plants, the boxwood family, Buxaceae Dumort. (Dumortier, 1822), together with Haptanthus A. Goldberg \& C. Nelson (Goldberg \& Nelson, 1989) and Didymeles Thouars (Thouars, 1804) form an old (Takahashi et al., 2017), distinct (Worberg et al., 2007; Gutiérrez, 2014), and diverse (about 140 species) taxon. They are distributed almost worldwide (Fig. 1) with high species diversity in Tropical America, Southern Africa / Madagascar, and East Asia (Jarvis, 1989; Köhler, 2004; Köhler, 2007; Köhler, 2009). They have no close relatives; the nearest branch on the phylogenetic tree of angiosperms are East Asian Trochodendron and Tetracentron, to which they were not even considered to be related before the "molecular era" (Castilho et al., 1999; Takhtajan, 2009).

There are multiple morphological characters which unite the group (Oskolski \& al., 2015), for example, cyclocytic or laterocytic stomata, frequently triplinerved leaf venation, racemose inflorescences, frequently dimerous flowers, stamen-sepalum complex in many representatives, and unusual pregnan steroidal alkaloids (Hardman, 1987; von Balthazar \& Endress, 2002a, b; von Balthazar et al., 2003; Köhler, 2007). 
Two anomalous genera of the group have been variously treated as independent families or as part of the Buxaceae. Haptanthus was discovered in Atlantida province of Honduras (Goldberg \& Nelson, 1989) and segregated as a monotypic family based on its perianth structure (Nelson, 2001; Shipunov, 2003), but the actual taxonomic position has been heavily deliberated (Doust \& Stevens, 2005; Goldberg \& Alden, 2005). As a result, it was accepted as the only incertae sedis genus of flowering plants by Takhtajan (2009) and even mentioned as such in the example 1 of ICN Article 3.1 ("Ex.1. The genus Haptanthus Goldberg \& C. Nelson (in Syst. Bot. 14: 16. 1989) was originally described without being assigned to a family...”). The locus classicus was apparently lost through deforestation, but Haptanthus was recently re-discovered (Shipunov \& Shipunova, 2010) and also found in more locations. Since then, it has been established ex situ in the Lancetilla Botanical Garden, Honduras (Bejarano, 2015). Both morphologically and molecularly, Haptanthus has similarities with the "core Buxaceae" as well as with Didymeles (Shipunov \& Shipunova, 2010; Oskolski \& al., 2015).

Geographically, Didymeles is close to the South African / Madagascan center of the group diversity, but until the "molecular era", it was not considered as a relative to the core Buxaceae (Worberg et al., 2007; Takhtajan, 2009). There are three (Köhler, 2007) or two (Madagascar Catalogue, 2018) accepted species but also some unidentified and putatively new material (Madagascar Catalogue, 2018). One of the most striking characters of Didymeles is the presence of a monomerous gynoecium (Leandri, 1937).

Among the core genera of the Buxaceae, Buxus (Linnaeus, 1753) is the most speciose (ca. 110 species) and wellknown (Larson, 1996) group. The infrageneric taxonomy of boxwoods is highly correlated with geography, and American and African species were at first considered as separate genera: the American Tricera (Schreber, 1797) and the African Notobuxus (Oliver, 1882). Van Tieghem (1897) split African Buxus in three genera, Buxanthus Tiegh., Buxella Tiegh., and Notobuxus. Later taxonomic revisions treated these as sections or subgenera, e.g., sect. Tricera (Schreb.) Baill. and subg. Probuxus Mathou (Baillon, 1859; see also Mathou, 1940). Though Buxus is widely distributed and highly diverse in comparison to other genera in the family, the apparently rapid speciation of Buxus on Cuba, which has almost 40 endemic boxwood species (Sauget \& Liogier, 1974; Köhler, 1998; Köhler, 2004; Köhler, 2006; Gutiérrez, 2014; Köhler, 2014), is remarkable relative to the diversity elsewhere. Despite their overall similarities, there are some substantial differences between these subgroups. For 
example, the Old World Buxus typically have cortical vascular bundles in each angle of the branchlets, accompanied by fiber strands in the Eurasian taxa (Köhler, 2004; Köhler, 2007), whereas both these characters are absent in New World Buxus.

The subfamily Pachysandroideae Record \& Garratt (or tribe Pachysandreae Reveal: Record \& Garratt, 1925; Reveal, 2011, 2012) is comprised of three genera: Pachysandra Michx., Sarcococca Lindl., and Styloceras Kunth. The three species of Pachysandra (Michaux, 1803) are herbaceous or suffruticose rhizomatous plants (Robbins, 1968), and their disjunct distributions are classic examples of the East Asian — Eastern North American floristic disjunction (Gray, 1846; Raven \& Axelrod, 1974). Pachysandra procumbens Michx. (“Allegheny spurge"), from North America, and P. terminalis Siebold \& Zucc. ("kichijiso") from Japan and China, are common garden plants used extensively as ground covers (Batchelor \& Miyabe, 1893; Dirr \& Alexander, 1979; Channell \& Wood, 1987). Pachysandra terminalis differs significantly from the two other species in its terminal inflorescences, strongly spreading rhizomatous habitat, bicarpellate gynoecium, and white baccate fruit. Pachysandra procumbens and the Chinese polymorphic P. axillaris Franchet have been shown to be sister species in molecular phylogenetic analyses (Jiao \& Li, 2009) despite their different appearance and the geographic proximity of the latter to $P$. terminalis.

The species of Sarcococca (Lindley, 1826) are small shrubs and understory plants of humid lowland and mountain forests, mostly in southeastern Asia. With their evergreen habit, winter-flowering, and fragrant flowers, the species of Sarococca are generally referred to as "Sweet Box" (Sealy, 1986). Sealy's (1986) revision was a first step in resolving some of the many taxonomic problems and specific boundaries in Sarcococca. Despite his efforts, regional floristic treatments do not recognize the same suite of taxa or the same synonymy (Backer \& Bakhuizen van den Brink, 1965; Min \& Brückner, 2008) and there is extensive variation in morphology across the distributions of some species. Sarcococca is also remarkable with the apparent geographic disjunction of $S$. conzattii (Standl.) I.M. Johnst., which occurs in southern Mexico (Oaxaca) and Guatemala (Johnston, 1939). It was first described as a Buxus (Standley, 1936; Johnston, 1938), but Sealy (1986) doubted it belonged there or with Sarcococca based on its morphology, inflorescence structure, and fruit type. 
The Andean Styloceras (Kunth, 1824) are small trees or shrubs, and with the exception of Buxus citrifolia (Willd.) Spreng. are the only representatives of Buxaceae in South America. Styloceras has been treated as a monogeneric family, the Stylocerataceae Takht. ex Reveal \& Hoogland (Reveal \& Hoogland, 1990), though it is now shown to be embedded within the Buxaceae (von Balthazar \& al., 2000). Six species are currently recognized (Gentry \& Aymard, 1993; Torrez \& Jorgensen, 2010; Ulloa Ulloa \& al., 2017), but we believe that the full diversity of this rare group is not yet understood.

The infra-familial classification of Buxaceae is still controversial. Mathou (1940) used two tribes, Buxeae Dumort. (with Buxus only) and Pachysandreae (with the other three genera of core Buxaceae), whereas Takhtajan (2009) essentially raised each genus into its own tribe. Reveal (2012) used two subfamilies, Pachysandroideae and Buxoideae Beilschm. (Beilschmid, 1833). The recent work on Buxus Caribbean taxa (Gutiérrez, 2014) provided a starting point for understanding the evolution of the significant portion of American boxwood species and group as a whole, but data about many other species, especially Old World, is still lacking. There is no recent synthetic classification of the family.

We attempt to provide a comprehensive classification scheme for Buxaceae through high taxonomic sampling that will serve as a framework for future studies in the group.

\section{Materials and Methods}

Our sampling protocol, due to the broad geographic distribution of the Buxaceae and rarity of many taxa, used herbarium material wherever possible for DNA extractions. We extracted DNA from 286 samples: 271 samples from herbaria and 15 from our collections. Herbarium tissue samples were obtained from numerous herbaria (B, BO, BRIT, CAS, F, HUH, IBSC, JEPS, NBG, NY, PE, PRE, SAM, SP, SPF, TI, US, and USM) with the kind permission of the herbarium curators. All vouchers were photographed so that the DNA sequence data could be linked to imaged specimens. Preference for a sample was always given to vouchers annotated by regional or generic experts. Besides, we supplemented missing data with 175 sequences from GenBank and Barcode of Life Data System (with necessary precautions: Funk \& al., 2018) of species or fragments which complemented our 
database. In total, we sampled all genera and 128 of 140 species (91\%) in Buxaceae. Only some rare and local species which are underrepresented in herbaria and living collections, were not sampled in our DNA dataset.

We used standard approaches for DNA extraction and employed commercial DNA extraction kits. DNA was extracted using either a MO BIO PowerPlant DNA Isolation Kit (MO BIO Laboratories, Carlsbad, California, USA) or NUCLEOSPIN Plant II Kit (MACHEREY-NAGEL GmbH \& Co. KG, Düren, Germany). Dry plant leaf material (typically, 0.05-0.09 g) was powdered using a sterile mortar and pestle and then processed in accordance with the supplied protocol. We increased the lysis time to 30 minutes and used thermomixer on the slow rotation speed $(350 \mathrm{rpm})$ instead of a water bath. Nanodrop 1000 Spectrophotometer (Thermo Scientific, Wilmington, DE, USA) was used to assess the concentration and purity (the $260 / 280 \mathrm{~nm}$ ratio of absorbance) of DNA samples. In our phylogenetic trees, we decided to integrate data from "barcoding" markers: plastid $r b c \mathrm{~L}$ plus trnL-F spacer and nuclear ITS to represent both chloroplast and nuclear genomes. Fortunately, herbarium specimens of Buxaceae typically retain DNA of relatively good quality for many years (Choi \& al., 2015). If the particular sample did not yield a sequence of good quality, we tried to use another sample of the same species.

We sequenced the markers mentioned above using primers and protocols in accordance with recommendations of the Barcoding of Life Consortium (Kuzmina \& Ivanova, 2011). PCR was carried out as follows: the reaction mixture in a total volume of $20 \mu \mathrm{L}$ contained 5.2 $\mu \mathrm{L}$ of PCR Master Mix (components from QIAGEN Corporation, Germantown, Maryland, and Thermo Fisher Scientific, Waltham, Massachusetts for Platinum DNA Taq Polymerase), $1 \mu \mathrm{L}$ of $10 \mu \mathrm{M}$ forward and reverse primers, $2 \mu \mathrm{L}$ of DNA solution from the extraction above and $10.8 \mu \mathrm{L}$ of either MQ purified water (obtained from a Barnstead GenPure Pro system, Thermo Scientific, Langenselbold, Germany), or the TBT-PAR water mix (Samarakoon \& al., 2013). Samples were incubated in a thermal cycler: $94^{\circ}$ for $5 \mathrm{~min}$, then 35 cycles of $94^{\circ}$ for $1 \mathrm{~min} ; 51^{\circ}$ (or similar, annealing temperature was varied with a primer) for $1 \mathrm{~min}, 72^{\circ}$ for $2 \mathrm{~min}$, and finally $72^{\circ}$ for $10 \mathrm{~min}$. Single-band PCR products were sent for purification and sequencing to Functional Biosciences, Inc. (Madison, Wisconsin) and sequenced there in accordance with standard protocol. Sequences were obtained, assembled, and edited using Sequencher ${ }^{\mathrm{TM}} 4.5$ (Genes Codes Corporation, Ann Arbor, Michigan, USA) and then aligned with AliView (Larsson, 2014) and MUSCLE (Edgar, 2004). 
For all procedures and statistic calculations, the R environment (R Core Team, 2019) was used. We used

Ripeline (Shipunov, 2020), the R-based DNA sequence analysis pipeline for databasing, sequence analysis, and phylogeny estimation. Ripeline is the combination of UNIX shell scripts and R scripts which allows for (a) species name checks using taxonomy database, (b) cross-validation of sequences, (c) updates from GenBank, (d) completeness analysis and species accumulation control, (e) deselection and replacement of outliers (both on the level of sequences and on the level of trees), (f) sequence alignments using the external tools, (g) flank cleaning, (h) gap coding based on Borchsenius (2009) algorithm which uses simple gap coding sensu Simmons and Ochotorena (2000), (i) smart (strict and semi-strict) concatenation (supermatrix production), and (j) a wide variety of phylogenetic outputs, from the k-mer alignment-free to Bayesian and maximal likelihood analyses. In addition, Ripeline is capable of using morphological characters, perform nearest neighbor imputation of missed sequences, and producing super-alignments (Ashkenazy \& al., 2018). The Ripeline is available from the primary author's Github: https://github.com/ashipunov/Ripeline. Within Ripeline, model testing and phylogenetic trees were made with APE (Paradis \& al., 2004), MrBayes (Ronquist \& Huelsenbeck, 2003), ips (Heibl, 2008), phangorn (Schliep, 2011) and RAxML (Stamatakis, 2014).

Before the alignment, sequence sets were constructed with the principle that sequences produced for this study had priority, and external data were added only to fill sampling gaps or to replace sequences of unreliable quality. This reduced any possible discrepancies based on incorrect identification and absence of proper vouchers in public databases (Funk \& al., 2018). Phylogenetic tree construction within Ripeline used both individual markers and their combinations (supermatrices, concatenated sequences). The preference was given to the concatenation of two sequences that originated from one (our) sample (strict concatenation). On the next (semistrict) stage, sequences with the same species name that were not derived from the same sample were concatenated.

Using Ripeline, we were able to obtain maximum likelihood (ML), Bayesian (MB), and maximum parsimony (MP) phylogenetic trees. Maximum likelihood analyses were run RAxML (Stamatakis, 2014) with 10,000 bootstrap replicates and $\mathrm{R}$ ips package (Heibl, 2008). We used a GTR+G+I model based on model testing with $\mathrm{R}$ phangorn package (Schliep, 2011). Bayesian analyses were run through the combination of MrBayes 3.2.6 
(Ronquist \& Huelsenbeck, 2003), and R shipunov package (Shipunov, 2019). MCMC chains were run for $1,000,000$ generations, sampling every 10 th generation resulting in 100,000 trees. The first $25 \%$ of trees were discarded as burn-in, and the remaining trees were summed to calculate the posterior probabilities. The convergence of Bayesian analyses was controlled using the standard deviation of frequencies across runs, and the potential scale reduction factor, PSRF (Ronquist \& Huelsenbeck, 2003). Maximum parsimony analyses were run with the help of R phangorn package (Schliep, 2011) using parsimony ratchet (Nixon, 1999) with 2000 iterations and then 1000 bootstrap replicates. With the aid of the R ape package (Paradis \& al., 2004), trees were rooted with Trochodendron aralioides and Tetracentron sinense as outgroups. To assess the congruence between chloroplast and nuclear data, we used the CADM test (Campbell \& al., 2011).

We used two kinds of supermatrices. The first was based on plastome (hereafter, CP) sequences only and included four chloroplast regions: $r b c \mathrm{~L}, \operatorname{trn} \mathrm{L}-\mathrm{F}, \operatorname{mat} K$ and $p e t D$. The second supermatrix (hereafter, OI) included two chloroplast sequences ( $r b c \mathrm{~L}$ and $t r n \mathrm{~L}-\mathrm{F})$ and also ITS2. Our plastome (CP) dataset was longer (5631 bp including 589, 1303, 2614, and 1125 bp of $r b c \mathrm{~L}, \operatorname{trn} \mathrm{L}-\mathrm{F}$, mat $K$, and petD parts, respectively) but covered less taxonomic diversity: all genera and 72 species (51\%). This matrix, therefore, follows the "more genes" approach (Rokas \& Carroll, 2005). The second matrix (OI), was shorter (2581 bp including 689 bp ITS) and was generated mostly from our data that covered all genera and 128 species (91\%) of the Buxaceae. To help with Pachysandroideae phylogeny estimation, we produced the third matrix (hereafter, "full ITS"), which uses full ITS sequences (generally, ITS1, 5.8S, and ITS2). This matrix covered five genera and 29 species of Buxaceae and was 1371 bp in length.

Datasets, scripts, and phylogenic trees used in the preparation of this publication are available from the first author's Open Repository here: http://ashipunov.info/shipunov/open/buxineae.zip. We encourage readers to reproduce our results and develop our methods further. All sequences were deposited into the GenBank (Support Table 3).

In the paper, we followed the "appropriate citation of taxonomy" (ACT) principle (Seifert \& al., 2008) and cited names of the most supra-species groups (Reveal, 2011, 2012) plus those species which are separately discussed. 


\section{Results}

In total, we obtained 359 sequences from 118 species (Support Table 3) and sequenced 50 species of Buxaceae for the first time. Of the resulting matrices that were analyzed, the average percentage of the data produced for this study (versus data which came from public databases) was near $74 \%$.

CADM test for the congruence between $r b c \mathrm{~L}+t r n \mathrm{~L}$ and ITS parts of OI supermatrix returned the average Kendall concordance value ( $\mathrm{W}=0.53576877)$, the null hypothesis of incongruence was rejected with $\mathrm{p}$-value 0.01598402 (Chi-squared=11341.15325383). In contrast to Rossello et al. (2007), we did not find issues with multiple copies of ITS present in samples.

In essence, MB, ML, and MP analyses resulted in very similar trees, and overall phylogeny is almost identical in MB and ML (Figs. 2-3). Below, we describe our results based on MB analyses of CP and OI supermatrices (Figs. 4-5), and ML analysis of "full ITS" matrix (Fig. 6). All trees are accessible from the open repository.

\section{Didymeles and Haptanthus}

Didymeles and Haptanthus were consistently recovered as the two first branches (Figs. 2-5). The Buxaceae as a whole, as well as a node next to Didymeles + Haptanthus grade, was supported well (BPP > 96\%) on CP and OI trees. A morphologically distinct (Fig. 7) sample of Didymeles from Toamasina (Madagascar) recovered as a first branch in the Didymeles clade (Fig. 4-5).

\section{Buxus}

Buxus s.l. is recovered as monophyletic with high support (Figs. 2-5). We sequenced 38 species of Buxus (35\%) for the first time. Within Buxus, three clades were recovered with as monophyletic (Figs. 4-5): an African clade with BPP 84-91\% across analyses, an American clade typically highly (BPP 100\%) supported, and a Eurasian clade with BPP 86-100\%.

The Eurasian clade of Buxus is not resolved well. Several South Asian species formed a basal subclade with low support (Fig. 5). This clade includes Buxus sirindhorniana W.K. Soh et al. from Thailand, B. rolfei S.Vidal and 
an unidentified sample from the Philippines, and the sample of unknown origin labeled in IBSC as "Buxus celebica Hats." Two other stable Asian subclades recovered (Fig. 5) in OI analyses, one consisted of B. myrica H.Lév., B. hainanensis Merr., B. latistyla Gagnep., and B. austroyunnanensis Hatus.; and another which was comprised of B. stenophylla Hance and B. megistophylla H.Lév.

Within the African Buxus clade (Figs. 4-5), species which were sometimes described under Notobuxus (like Buxus cordata (Radcl.-Sm.) Friis) were present together with species from Buxus s.str. (like B. hildebrandtii Baill. and B. madagascarica Baill.). Support of smaller clades varied but BPP typically was above 50\%.

The American clade was the most speciose in our datasets. The first branches form a grade, which includes $B$. bartlettii Standl., B. pubescens Greenm., B. moctezumae Eg.Köhler, R.Fernald \& Zamudio and B. mexicana Brandegee. Buxus jaucoensis Eg.Köhler does not hold a stable position on our trees; it is frequently sister to most or all subclades. The next branches were mostly Cuban species (for example, Buxus koehleri P.A.González \& Borsch, B. flaviramea (Britton) Mathou, B. obovata Urb., B. vaccinioides (Britton) Urb.). The last big subclade includes many non-Cuban species, for example, Buxus portoricensis Alain and B. citrifolia (Figs. 4-5). Some Cuban species (for example, Buxus "rotundifolia", see below about this name) also branch here.

\section{Pachysandroideae Record et Garratt}

The results of all phylogenetic analyses of the matrices recovered a monophyletic Pachysandroideae (Figs. 2-6). Sarcococca was not monophyletic on CP and "full ITS" trees, and the New World S. conzattii was either robustly placed as sister to the other genera of the subfamily ("full ITS"), as sister to Styloceras + Pachysandra (CP) with high support, or (OI) as sister to the remaining species of Sarcococca (with low support).

Seven species of Sarcococca were sequenced for the first time (Fig. 5). There was high support (OI) for $S$. confertifolia Sealy, S. longipetiolata M. Cheng, S. orientalis C.Y. Wu, and S. philippinensis Stapf ex Sealy group. This clade was the first branch in Sarcococca s.str., and the remainder of the Sarcococca species formed another stable clade. This last clade includes the recently described Vietnamese S. bleddynii J.M.H.Shaw \& N. van Du (Shaw, 2011), S. euphlebia Merrill from Hainan, unidentified Sarcococca sp. from Myanmar as a sister group to S. zeylanica Baill., and seven other species. 
Pachysandra was not recovered as monophyletic in all analyses. Whereas a monophyletic Pachysandra presents in CP analyses with low support (Fig. 4), it was not monophyletic on OI and "full ITS" trees. On OI trees,

Pachysandra terminalis was recovered as sister to Styloceras with high support (Fig. 5), and on "full ITS" trees, it was placed between Sarcococca conzattii and the remainder of the Pachysandroideae, albeit with low support (Fig. 6).

Four (out of six) species of Styloceras were sequenced for the first time. On OI trees, Styloceras is monophyletic and well-supported (Fig. 5). Styloceras laurifolium (Willd.) Kunth is sister to five other species of the genus with the reliable support; two other clades consisted of S. kunthianum A. Juss., S. penninervium A.H. Gentry \& G.A. Aymard and S. connatum Torrez \& P. Jørg. (BPP 94\%) and S. columnare Müll.Arg. + S. brokawii .H.Gentry \& R.B.Foster (BPP 100\%). An unidentified sample of Styloceras from Oxapampa (Peru) is morphologically similar to S. penninervium and was placed sister to it on OI trees (Fig. 5).

\section{Discussion}

Our dataset provides the most broadly sampled phylogenetic analyses of Buxaceae to date. In some groups, the amount of molecular information is doubled, and even tripled (Styloceras). Our molecular phylogenetic results support the elevation of Sarcococca conzattii into a new genus, Sealya (described below).

\section{Didymeles and Haptanthus}

Buxaceae sensu lato is robustly supported in all our analyses (Figs. 2-5). Didymeles and Haptanthus form two earliest lineages sister to the remainder of Buxaceae. The analyses resulted in an equivocal placement of Haptanthus and Didymeles, which is in agreement with the earlier analyses (Shipunov \& Shipunova, 2011). This instability versus the stability of Buxaceae sensu lato provides an indirect support of the integrity of the whole group. As both our results and the morphology of these two distinct genera support a close relationship to the core Buxaceae (Oskolski \& al., 2015; Takahashi et al., 2017), we include them in the Buxaceae sensu lato as distant, early diverging lineages. This inclusion necessitates the description of the two new subfamilies in Buxaceae (see below). 
Buxus

In Buxus s.l. three distinctive clades were recovered that correspond perfectly to their geographic distributions. The Eurasian species were sister to the remaining Buxus comprised of a New World and sub-Saharan African clade sister to one another. This topology is similar to that of von Balthazar \& al. (2000) and Gutiérrez (2014), and all newly sequenced data fit well with these three geographical clades.

Classification of Buxus as a single genus vs. multiple genera is still contentious. The recognition of Notobuxus separate from Buxus is frequently but not totally accepted ( $c f$. Friis, 1989; von Balthazar et al., 2000; Köhler, 2007, 2009). At the same time, the monophyletic Tricera has often been included in Buxus despite being molecularly closer to Notobuxus (von Balthazar et al., 2000). A reasonable approach based on the data presented here that does not require extensive nomenclature changes, is to recognize an inclusive Buxus with three wellsupported monophyletic clades; we treat these Eurasian, African and American clades at a subgeneric level.

The Eurasian Buxus are highly diverse in southeastern Asia, with two or more species extending west to Europe (Köhler \& Brückner, 1989; van Laere at al., 2011). The recently described Buxus sirindhorniana from Thailand (Soh \& al., 2014; Soh \& Parnell, 2018) and B. rolfei from the Philippines are members of the earliest lineage to diverge in the Eurasian Buxus. Our topologies (Fig. 4-5) do not recover the proposed infrageneric divisions of Mathou (1940) and Hatusima (1942). Of Hatusima's (1942) informal groups, none are recovered as monophyletic though some of the species that form parts of his groups (namely, "Group I") do form wellsupported clades, e.g., B. myrica, B. hainanensis, B. latistyla, and B. austroyunnanensis. This last grouping also corresponds with the more recent review of Tianlu \& Brückner (2008).

Buxus from Africa and Madagascar have variously been split into distinct genera separate from Buxus, or included within a broad Buxus (Van Tieghem, 1897; Friis, 1989; Schatz \& Lowry II, 2002). Friis (1989) recognized three sections in African Buxus: sect. Tricera (Swartz ex Schreb.) Baill. including only B. hildebrandtii, sect. Notobuxus (Oliv.) Friis and sect. Buxella (Tiegh.) Hutch. These divisions are also supported by palynology (Köhler \& Brückner, 1982; Köhler \& Brückner, 1989; Köhler, 1994). Our molecular CP and OI analyses supported the recognition of sect. Buxella, excluded B. hildebrandtii from New World Tricera but did 
not fully resolve relationships between B. hildebrandtii and "sect. Notobuxus" species. We treat the African clade as subg. Notobuxus, a single monophyletic group; subclades recovered here might support further sectional divisions.

American Buxus clade forms a well-supported monophyletic taxon endemic to the Neotropics with a single migration and rapid diversification in the Caribbean-Cuban Buxus species (Köhler, 2014; Gutiérrez, 2014). Our CP trees were in line with Gutiérrez (2014). OI trees were different but overall support was much lower, and we cannot fully exclude the effect of putative ITS paralogues (Rosello et al., 2007; Gutiérrez, 2014). In all, we believe that barcoding markers are not powerful enough in cases of rapid diversification, and this group still awaits detailed research. However, but we were able to place there some newly sequenced species (Fig. 5), for example, B. lancifolia and B. vaccinioides.

\section{Pachysandroideae}

The Pachysandroideae is united by is crotonoid pollen (Gray \& Sohma, 1964; Köhler, 2007; see also Fig. 8), but the genera are otherwise morphologically distinctive. Our results of the Pachysandroideae present a topology (Figs. 2-6) where the long-questionably placed Sarcococca conzattii (Fig. 8) was consistently recovered separate from all other species of Sarcococca. In our analyses, it branches distantly from the rest of Sarcococca (OI, and especially "full ITS": Figs. 5-6) or as a lineage sister to the Sarcococca (CP: Fig. 4). We used molecular data as an additional evidence and is herein recognized a novel monotypic genus, Sealya (see below).

Sealya was nearly concurrently described in both Buxus and Sarcococca (Standley, 1936; Johnston, 1938), and its inclusion within Sarcococca was based on vegetative similarities (alternate, subcoriaceous leaves) and similar fruit types. However, it differs from Sarcococca in its inflorescence structure, which is similar to that of Buxus in having a terminal female flower; furthermore, its terminal female flowers possess the well-developed tepals and bracteoles (Sealy, 1986; Köhler, 2007). Its fruits are indehiscent like in Sarcococca, but have dry mesocarps and are white in contrast to the Sarcococca s.str. blackish-blue or reddish fruits (Sealy, 1986). Sealya shares the crotonoid pollen exine (Fig. 8) with all other members of Pachysandroideae (Köhler, 2007). 
With Sealya excluded, Sarcococca is monophyletic in all our analyses. Even with our still limited sampling, it appears that the diversity in Sarcococca is higher than current taxonomic treatments recognize (Sealy, 1986; Min \& Brückner, 2000). For example, our analyses recovered S. euphlebia and S. balansae separately and distantly placed, but Sealy (1986) placed S. euphlebia as a synonym of S. balansae. In contrast, Min and Brückner (2000) placed both as synonyms of $S$. vagans (which we did not sample). Inclusion of $S$. vagans might result in one of the preceding species being supported as a synonym, but not both. Additional systematic work is needed with a comprehensive sampling of widespread species to resolve taxonomy in Sarcococca.

Despite the low species number and relatively high level of systematic investigation (Robbins, 1968; Boufford \& Xiang, 1992; von Balthazar et al. 2000; Jiao \& Li, 2009), Pachysandra also presents a potential for the further studies. Our OI and "full ITS" analyses (Figs. 5-6) point on the possible separation of the Pachysandra terminalis from two other species of the genus. Morphologically, it differs from two other species in its terminal inflorescences, two-carpellate gynoecium, the smaller stigmatic region encompassing on the distal third of the style, the male flowers subtended by a coriaceous bract and two bracteoles, elongate multi-bracted pedicels of the pistillate flowers, white baccate fruits, and adaxially raised leaf veins (Robbins, 1968). Future molecular research should sample even more extensively and include $P$. terminalis from both areas of its distribution (Japan and China) as well as the broadly distributed and morphologically diverse P. axillaris.

Our coverage of Styloceras is comprehensive and represented here by seven samples and six species. Styloceras laurifolium holds the most basal position while the rest of the genus form two clades with the reliable support: $S$. penninervium + S. kunthianum + S. connatum, and S. brokawii + S. columnare. This topology does not correspond well with existing review (Torrez \& Jorgensen, 2010) which places S. kunthianum, S. columnare and S. laurifolium together and separates $S$. penninervium from the rest of the genus. Given the scarcity of information and collections, and difficulties in DNA amplification in Styloceras, we believe that this is only a first step towards understanding the diversity of this rare and unusual Neotropical group.

\section{Taxonomic Treatment}




\section{Didymeles toamasinae Floden et Shipunov, sp.nov.}

Differs from Didymeles perrieri Leandri by smaller leaves $(30-50 \times 15-30 \mathrm{~mm} v \mathrm{~s} .50-100 \times 30-37 \mathrm{~mm})$, intensively branching shoots, thinner terminal branches (1.5-2 vs. 2-4 mm diam.), and smaller (12-15 vs. 15-20 $\mathrm{mm}$ ) mature fruits.

TYPE:-Toamasina. Fivondronana: Maroantsetra. Commume: Antisrasbesahatany. Fokontany: Anjiahely. Beanivona forest. Collected with Pascal, Ramaroson, Saside and David. 15²3'56"S 045²6'32"E. 746 m. Tree 8 m tall, DBH 20 cm, fruits nearly mature. 17 December 2002. P. Antilahimena \& al. 1529 (holotype: MO!)

Etymology:- Named after the region of collection, Toamasina, northeastern Madagascar.

Distribution:-MADAGASCAR, northeast, Atsinanana region. (MO P. Antilahimena 2497a!, MO P. Antilahimena, Pascal \& Ramaroson 1561!)

Description:- Small trees 4-8 m, young stems 1-2 mm diam., internodes $2-4 \mathrm{~cm}$. Leaves with petioles $1.2-1.5$ $\mathrm{cm}$, laminas 3-5 × 1.5-3 cm, elliptic, apex acuminate, base cuneate, with visible primary and secondary venation. Flowers not seen. Fruits $1.2-1.5 \mathrm{~cm}$, ellipsoid, stylar remnants about $2 \mathrm{~mm}$.

\section{Buxus cyclophylla Floden \& Shipunov, nom.nov.}

As the Cuban Buxus rotundifolia (Britton) Mathou is the latter homonym of Buxus rotundifolia K.Koch, we propose a new name for the former:

Buxus cyclophylla Floden \& Shipunov, nom.nov. pro Buxus rotundifolia (Britton) Mathou, Rech. Fam. Buxac. 229 (1939). nom.illeg., non Buxus rotundifolia Hort. ex K.Koch, Dendrologie 2(2): 479 (1873).

ETricera rotundifolia Britton, Bull. Torrey Bot. Club 42: 500 (1915).

Type: - NY Shafer 114! Between Camp La Barga and Camp San Benito, about 1,000 m alt., northern Oriente. 


\section{Sealya Floden et Shipunov gen. nov.}

Differs from Sarcococca by its inflorescence terminated by a female flower ( vs. male), male and female flowers with well-developed tepals ( $v s$. weakly differentiated as perianth organs), bracteoles prominent, and by its white fruit (vs. purple to red) with dry mesocarp (vs. fleshy mesocarp), while it also differs from Buxus by having alternate leaves, bicarpellate ovary ( $v s$. tri), and fleshy, drupe-like fruit ( $v s$. dry and dehiscent).

Generic type:

Sealya conzattii (Standl). Floden et Shipunov comb. nov. TYPE:-Mexico, C. Conzatti 2508 (holotype: F digital image!; isotypes: EAP87195 digital image!, G00359411 digital image!, US digital image!).

Basionym:-Buxus conzattii Standley, Publications of the Field Museum of Botany, 11: 163 (1936).

SYNONYMS:-Sarcococca conzattii (Standley) I. M. Johnston, Journal of the Arnold Arboretum, 20: 240 (1939); S. guatemalensis I. M. Johnston, Journal of the Arnold Arboretum, 19: 121 (1938). — Type: Guatemala, A.F. Skutch 288 (holotype: A00048976 digital image!; isotype: K000573596 digital image!, MICH digital image!, TX/LL!, US digital image!)

Etymology:- Named in honor of J. Robert Sealy who stated in his 1986 revision of Sarcococca that the generic placement of S. conzattii in Sarcococca was incorrect and its placement in Buxus would be "equally anomalous."

Distribution:-MEXICO. Chiapas, Oaxaca. GUATEMALA, occurring at mid-to higher elevations.

Buxus subgenus Notobuxus (Oliv.) Floden et Shipunov, subg.nov.

Basionym: — Notobuxus Oliv. in Hook, Ic. Pl. 14:78, t 1400. 1882. Type: — B. natalensis (Oliv.) Hutch., Africa, Natal, Inanda, Wood 1357 (lectotype (designated here), K, isolectotypes, BOL136821, BOL136822, NH0001717-1, NH0001717-2).

Subgenus Notobuxus has been repeatedly shown in molecular studies to be a monophyletic group of African and Malagasy species (Gutiérrez, 2014; von Balthazar \& al., 2000). It is characterized by frequently sessile anthers, and by 
the frequent presence of multiple (6-10) stamens and flat disk-shaped pistillode (Friis, 1989; von Balthazar \& Endress, 2002a; Köhler, 2007). Notobuxus Oliv. was based on two separate collections that represent syntypes because no type was designated (Article 9.3: Turland \& al., 2018). From the original material (Article 9.4) cited by Oliver (1882) there was a collection with unopened flowers (T. Cooper 3465, K) and a collection by Wood 1357 with opened flowers. The accompanying illustration (Oliver, 1882: Plate 1400) was drawn from the latter, thus we select Wood 1357 to serve as the lectotype.

Buxus subgenus Tricera (Swartz ex Schreb.) Floden et Shipunov, subg.nov.

Basionym: - Tricera Swartz ex Schreb., Gen. 630. 1791. Type:-B. laevigata (Sw.) Spreng. Jamaica, O.P. Swartz (holotype S, isotypes G, LD).

Subgenus Tricera is wholly New World and differs from the subgenus Buxus and subgenus Notobuxus by the absence of cortical vascular bundles in the angle of the branchlets (Köhler, 2007). The results of the molecular phylogeny support subg. Tricera as a robust monophyletic group endemic to the New World.

\section{Didymeloideae Floden \& Shipunov, subfam. nov.}

Didymeloideae Floden \& Shipunov, subfam. nov. - Type: Didymeles Thouars

Distribution. - Madagascar.

Genera (1). - Didymeles Thouars

\section{Haptanthoideae Floden \& Shipunov, subfam. nov.}

Haptanthoideae Floden \& Shipunov, subfam. nov. - Type: Haptanthus A. Goldberg \& C. Nelson

Distribution. - Central America, Honduras, Atlantida province.

Genera (1). - Haptanthus A. Goldberg \& C. Nelson 
Differs from Pachysandra by its terminal inflorescences, gynoecium with two-carpels, a stigmatic region encompassing only the distal third of the style, male flowers subtended by a coriaceous bract and two bracteoles, the elongate multi-bracted pedicels of the pistillate flowers, its white baccate fruits, and its adaxially raised leaf veins.

Etymology: The generic name, Kichijiso, is one of the Japanese common names of this plant (Batchelor \& Miyabe, 1893: "Kichijisô, the fruit of which are eaten raw"). This selection of the generic name follows other Latinized generic names such as Aucuba, Kirengeshoma, Nandina, and Sasa (Stearn, 2004).

Distribution: Japan and eastern China (Min Tianlu \& Brückner, 2008)

Generic type:

Kichijiso terminalis (Sieb. et Zucc.) Floden et Shipunov comb. nov. TYPE:- (lectotype selected by Robbins, 1960) Japonia, 1842, Siebold, P.F. von, s.n. (M-0120840).

Basionym:-Pachysandra terminalis Siebold \& Zuccarini, Abh. Math.-Phys. Cl. Königl. Bayer. Akad. Wiss. 4(2): 142. 1845.

\section{Conclusion}

With the broad taxonomic sampling, we provide a comprehensive approach to improve the classification scheme of the Buxaceae. We hope that our results might serve as a framework for future studies in the group, which will eventually reach the highest phylogenetic accuracy. The use of short barcoding molecular markers is likely the best choice for our mostly herbarium-oriented approach. However, at the same time, we argue that more in-depth research that incorporates data on genomics, morphology, anatomy, chemistry, distribution, and fossil history is required to provide overall integrative and synthetic revisions of the genera of the Buxaceae.

\section{Key to the Buxaceae sensu lato}

1 Plants dioecious; flowers apetalous; male with one stamen pair; female flowers paired, carpels single and uniovulate, seeds exalbuminous ... Didymeles (subfam. Didymeloideae)

- Plants monoecious; flowers with weakly differentiated perianth parts; male flowers with decussate tepals, 2, 4, or 6-10 stamens; female with spiraled tepals, carpels bi- to pluri-ovulate, seeds albuminous ... 2

2 Flowers apparently naked; male flowers with two stamens fused into one staminate organ; female flowers 3carpellate, carpels pluri-ovulate (8-15), placentation parietal ... Haptanthus (subfam. Hapanthoideae)

- Flowers with perianth; male flowers with free stamens, female flowers 2-3-carpellate, carpels bi-ovulate, placentation axile ... 3

3 Tepals absent in male flowers, stamens numerous; rudiment of ovary wanting ... Styloceras (subfam. Pachysandroideae) 
4 Leaves decussate; female flowers terminal in racemes or clusters; fruit a 3-valved capsule ... 5 (Buxus, subfam. Buxoideae)

- Leaves alternate; female flowers at base of racemes or spikes; fruit more or less drupaceous ... 7 (the rest of subfam. Pachysandroideae)

5 Cortical vascular bundles wanting (American) ... Buxus subg. Tricera

- Cortical vascular bundles in each angle of the branches ... 6

6 Cortical vascular bundles with fibre strands; male flowers with 4 stamens, anthers long exserted; pistillode present ... Buxus subg. Buxus

- Cortical vascular bundles without fibre strands; male flowers with (4) 6-10 stamens; anthers usually sessile; pistillode as a flat disk, or absent ... Buxus subg. Notobuxus

7 Woody shrubs or small trees; leaves entire; fruit more or less drupaceous ...8

- Perennial herbs with procumbent stems; leaves serrate to dentate or deeply toothed; flowers borne at the base of the stem or terminally; fruit an indehiscent capsule or subdrupaceous ...9

8 Female flowers lateral on inflorescences; gynoecium 2- or 3-carpellate; fruit drupaceous, reddish, purple, or blackish ... Sarcococca

- Female flowers terminal on inflorescences; gynoecium 2-carpellate; fruit with dry mesocarp, white ... Sealya

9 Inflorescences at base of stem or proximal axils; gynoecium 3-carpellate; fruits reddish-brown, indehiscent capsule ... Pachysandra (P. axillaris and P. procumbens)

- Inflorescences terminal; gynoecium 2-carpellate; fruits white, subdrupaceous ... Pachysandra terminalis (Kichijiso terminalis)

\section{Author Contributions}


AS provided the design of the research; AF and AS performed data analysis, interpretation and writing of the manuscript; all co-authors participate in data collection.

\section{Literature cited}

Ashkenazy, H., Sela, I., Levy Karin, E., Landan, G. \& Pupko, T., 2018. Multiple sequence alignment averaging improves phylogeny reconstruction. Syst. Biol. 68: 117-130.

Backer, C.A. \& Bakhuizen van den Brink, R.C. 1965. Flora of Java 1: 646-647.

Baillon, H. 1859. Monographie des Buxacées et des Stylocérées. Paris, Victor Masson.

Batchelor, J. \& Miyabe, K. 1893. Ainu economic plants. Yokohama, 1893.

Beilschmid, C.T. 1833. J. Lindley's characteres distinctivi oder Hauptkennzeichen der natürlichen Pflanzenfamilien. Flora. 16: 49-112

Bejarano, L. 2015. Reporte y caracterización de poblaciones, fenología y descripción del fruto de Haptanthus hazlettii, una especie endémica de Honduras. Tatascán. 25: 31-41.

Borchsenius, F. 2009. FastGap 1.2. Department of Biosciences, Aarhus University, Denmark. URL: http://www.aubot.dk/FastGap_home.htm (accessed Aug 27 2019).

Boufford, D.E. \& Xiang, Q.Y. 1992. Pachysandra (Buxaceae) reexamined. Bot. Bull. Acad. Sinica. 33: 201-207.

Campbell, V., Legendre, P. \& Lapointe, F.-J. 2011. The performance of the Congruence Among Distance Matrices (CADM) test in phylogenetic analysis. BMC Evol. Biol. 11: 64.

Castilho, R.O., Bulhões, A.A.D.S. \& Kaplan, M.A.C. 1999. Controversy in Buxales systematic positioning. Nord. J. Bot. 19: 541-546.

Channell, R.B. \& Wood, C.E. 1987. The Buxaceae in the southeastern United States. J. Arnold Arb. 68: 241257. 
Choi, J., Lee, H. \& Shipunov, A. 2015. All that is gold does not glitter? Age, taxonomy, and ancient plant DNA quality. PeerJ. 3:e1087.

Dirr M.A. \& Alexander J.H. 1979. Allegheny Pachysandra. Arnoldia 39: 16-21.

Doust, A.N. \& Stevens, P.F. 2005. A reinterpretation of the staminate flowers of Haptanthus. Syst. Bot. 30: 779785.

Dumortier, B.C. 1822. Commentationes Botanicae. P. 54.

Edgar, R.C. 2004. MUSCLE: multiple sequence alignment with high accuracy and high throughput. Nucleic Acids Res. 32(5): 1792-1797.

Friis, I. 1989. A synopsis of the Buxaceae in Africa south of the Sahara. Kew Bull. 44: 293-299.

Funk, V.A., Edwards, R. \& Sterling, K. 2018. The problem with(out) vouchers. Taxon 67: 3-5.

Gentry, A.H. \& Aymard, G. 1993. A new species of Styloceras (Buxaceae) from Peru. Novon. 3: 142-144.

Gentry, A.H. \& Foster R. 1981. A new Peruvian Styloceras (Buxaceae): discovery of a phytogeographical missing link. Ann. Missouri Bot. Gard. 68: 122-124.

Goldberg, A. \& Alden H.A. 2005. Taxonomy of Haptanthus Goldberg \& C. Nelson. Syst. Bot. 30: 773-778.

Goldberg, A. \& Nelson, C.S. 1989. Haptanthus, a new dicotyledonous genus from Honduras. Syst. Bot. 14: 1619.

Gray, A. 1846. Analogy between the flora of Japan and that of the United States. Am. J. Sci. ser. 2, 2:135-136.

Gray, J. \& Sohma, K. 1964. Fossil Pachysandra from western America with a comparative study of pollen in Pachysandra and Sarcococca. Am. J. Sci. 262: 1159-1197.

Gutiérrez P.A.G. 2014. Evolution and biogeography of Buxus L.(Buxaceae) in Cuba and the Caribbean. Dissertation. Berlin: Freie Universität. 
Gutiérrez, P.A.G. \& Borsch, T. 2013. New species of Buxus (Buxaceae) from northeastern Cuba based on morphological and molecular characters, including some comments on molecular diagnosis. Willdenowia. 43: $125-137$.

Hardman, R. 1987. Recent developments in our knowledge of steroids. Planta Medica 53: 233-238.

Hatusima, S. 1942. A revision of the Asiatic Buxus. Journal of the Faculty of Agriculture, Kyushu University 6: 261-342.

Hazlett, D.L. 2016. Especies taladas, volumen de madera extraído y un árbol endémico raro (Haptanthus) de un Bosque Hondureño de Tierras Bajas. Ceiba. 53: 81-94.

Heibl, C. 2008. IPS: R language tree plotting tools and interfaces to diverse phylogenetic software packages. URL: https://github.com/heibl/ips (accessed Aug 27 2019).

Reveal, J.L. \& Hoogland, R.D. 1990. Validation of five family names in the Magnoliophyta. Bulletin du Muséum national d'histoire naturelle. Section B, Adansonia 12: 205-208.

Huelsenbeck, J.P., \& Ronquist, R. 2001. MRBAYES: Bayesian inference of phylogenetic trees. Bioinformatics 17: 754-755.

Jarvis, C.E. 1989. A review of the family Buxaceae Dumortier. Pp. 274-278 in: Crane P.R., Blackmore S. (eds). Evolution, systematics, and fossil history of the Hamamelidae. Clarendon Press, Oxford.

Jiao, Z. \& Li, J. 2009. Phylogenetics and biogeography of eastern Asian-North American disjunct genus Pachysandra (Buxaceae) inferred from nucleotide sequences. J Syst. Evol. 47: 191-201.

Johnston, I.M. 1938. Some undescribed species from Mexico and Guatemala. J Arnold Arbor. 19: 117-128.

Johnston, I.M. 1939 New phanerogams from Mexico. J Arnold Arbor. 20: 234-240.

Köhler, E. \& Brückner, P. 1982. Die pollenmorphologie der afrikanischen Buxus-und Notobuxus-arten (Buxaceae) und ihre systematische bedeutung. Grana, 21: 71-82. 
Köhler, E. \& Brückner, P. 1989. The genus Buxus (Buxaceae): aspects of its differentiation in space and time.

Plant Syst. Evol. 162: 207-283.

Köhler, E. 1994. Parallel evolution of pollen characters in the genus Buxus L.(Buxaceae). Acta Bot Gallica. 141: $223-232$.

Köhler, E. 1998. Weitere neue Buxus- Arten der Flora von Cuba. Feddes Repert. 109: 351-363.

Köhler, E. 2004. Buxaceae. Pp. 70-72 in: Smith, N., Mori, S.A., Henderson, A., Stevenson, D.W. \& Head, S.W. (eds.). Flowering Plants of the Neotropics. Princeton University Press, Princeton.

Köhler, E. 2006. Three new Buxus species (Buxaceae) from eastern Cuba. Willdenowia. 36: 479-489.

Köhler, E. 2007. Buxales. Buxaceae. Didymelaceae. In: K. Kubitzki (ed.). Flowering Plants: Eudicots. IX. Berlin, Heidelberg: Springer.

Köhler, E. 2009.Neotropical Buxaceae. In: Milliken, W., Klitgård, B. \& Baracat, A. 2009-. Neotropikey— Interactive key and information resources for flowering plants of the Neotropics. URL:

http://www.kew.org/science/tropamerica/neotropikey/families/Buxaceae.htm (accessed 29 Aug 2019).

Köhler, E. 2014. Buxaceae. Flora de la Republica de Cuba. 19: 1-124.

Kunth, K.S. Styloceras In: Jussieu, A. 1824. De Euphorbiacearum Generibus medisque earumdem viribus tentamen. Paris 17: 53.

Kuzmina, M., Ivanova, N. 2011. Primer sets for plants and fungi. URL: http://ccdb.ca/site/wpcontent/uploads/2016/09/CCDB_PrimerSets-Plants.pdf (accessed 29 Aug 2019).

Larson, P.D. 1996. Boxwood: its history, cultivation, propagation and descriptions. Foliar Press, Boyce, VA.

Larsson, A. 2014. AliView: a fast and lightweight alignment viewer and editor for large data sets.

Bioinformatics. 30: 3276-3278.

Leandri, J. 1937. Sur 1'aire et la position systematique du genre malgache Didymeles Thouars. Annales des sciences naturelles. Botanique. Series 10. 19: 304-318. 
Lindley J. 1826 Botanical Register; Consisting of Coloured Figures of Exotic Plants Cultivated in British Gardens; with their History and Mode of Treatment. Vol. 12. London

Linnaeus C. 1753. Species Plantarum. Holmiae.

Madagascar Catalogue. 2018. Catalogue of the Vascular Plants of Madagascar. Missouri Botanical Garden, St. Louis, U.S.A. \& Antananarivo, Madagascar. URL: http://www.tropicos.org/Project/Madagascar. (Accessed Aug 29 2019)

Mathou, Th. 1940. Recherches sur le famille des Buxacées. Douladoure, Toulouse.

Michaux, A. 1803. Flora Boreali-Americana. Vol. 2. Caroli Crapelet, Paris.

Min Tianlu \& Brückner, P. 2008. Buxaceae. In: Flora of China. 11: 321-332.

Nelson, C.S. 2001. Plantas descritas originalmente de Honduras y sus nomenclaturas equivalentes actuales. Ceiba. 42: 1-71.

Nixon, K.C. 1999. The parsimony ratchet, a new method for rapid parsimony analysis. Cladistics, 15: 407-414.

Oliver, D. 1882. Notobuxus natalensis. Hooker's Icones Plantarum; or Figures, with brief Descriptive Characters and Remarks of New or Rare Plants. 4: 78.

Oskolski, A., von Balthazar, M., Staedler, Y.M. \& Shipunov, A.B. 2015. Inflorescence and floral morphology of Haptanthus hazlettii (Buxaceae, Buxales). Bot. J. Linn. Soc. 179: 190-200.

Paradis, E., Claude, J. \& Strimmer, K. 2004. APE: analyses of phylogenetics and evolution in R language. Bioinformatics 20: 289-290.

R Core Team. 2019. R: A language and environment for statistical computing. R Foundation for Statistical Computing, Vienna, Austria. URL: http://www.R-project.org/ (Accessed Aug 30, 2019)

Raven, P.H. \& Axelrod, D.I. 1974. Angiosperm biogeography and past continental movements. Ann. Missouri Bot. Gard. 61: 539-673. 
Record S.J. \& Garratt G.A. Boxwoods. Yale University School of Forestry Bulletin. 14.

Reveal, J.L. 2011. Indices nominum supragenericorum plantarum vascularium. Alphabetical listing by genera of validly published suprageneric names. URL: http://www.plantsystematics.org/reveal/pbio/fam/allspgnames.html (Accessed Aug 30, 2019)

Reveal, J.L. 2012. An outline of a classification scheme for extant flowering plants. Phytoneuron. 37: 1-221.

Robbins, H.C. 1968. The genus Pachysandra (Buxaceae). Sida. 3: 211-248.

Rokas, A. \& Carroll, S.B. 2005. More genes or more taxa? The relative contribution of gene number and taxon number to phylogenetic accuracy. Molecular Biology and Evolution. 22: 1337-1344.

Ronquist, F. \& Huelsenbeck, J.P. 2003. MrBayes 3: Bayesian phylogenetic inference under mixed models. Bioinformatics. 19: 1572-1574.

Rossello, J.A., Lazaro, A., Cosín, R., Molins, A. 2007. A phylogeographic split in Buxus balearica (Buxaceae) as evidenced by nuclear ribosomal markers: when ITS paralogues are welcome. Journal of Molecular Evolution. 64: $143-157$.

Samarakoon, T., Wang, S.Y. \& Alford, M.H., 2013. Enhancing PCR amplification of DNA from recalcitrant plant specimens using a trehalose- based additive. Applications in Plant Sciences. 1: 1200236.

Sauget, J.S. \& Liogier, E.E. 1974. Buxaceae. Flora de Cuba. 2:140-146.

Schatz, G.E. \& Lowry II, P.P. 2002. A synoptic revision of the genus Buxus L.(Buxaceae) in Madagascar and the Comoro Islands. Adansonia. 3: 7-19.

Schliep, K.P. 2011. phangorn: phylogenetic analysis in R. Bioinformatics. 27: 592-593.

Schreber, J.C.D. 1797. Tricera. In: Swartz O. Flora Indiae Occidentalis. 1: 331-334.

Sealy, J.R. 1986. A revision of the genus Sarcococca (Buxaceae). Bot. J. Linn. Soc. 92: 117-159. 
Seifert, K. A., Crous P.W. \& Frisvad J.C. 2008. Correcting the impact factors of taxonomic journals by appropriate citation of taxonomy (ACT). Persoonia 20: 105.

Shaw, J. 2011. New introductions from northern Vietnam. Plantsman. 10: 232-237.

Shipunov, A. \& Shipunova E. 2011. Haptanthus story: Rediscovery of enigmatic flowering plant from Honduras. Am. J. Bot.. 98: 761-763.

Shipunov, A. 2003. The system of flowering plants: synthesis of classical and molecular approaches. Zhurnal Obshchei Biologii. 64: 501-509.

Shipunov, A. 2019. shipunov: Miscellaneous Functions from Alexey Shipunov. R package. URL: https://CRAN.R-project.org/package=shipunov (Accessed Mar 19 2020)

Shipunov, A. 2020. Ripeline and Rmanual speed up biological research and reporting. arXiv preprint arXiv:2002.01475.

Siebold, Fr. de \& Zuccarini J.G. 1845. Florae Japonicae Familiae Naturales. Sec. 1. Abhandlungen der Mathematisch-Physikalischen Classe der Königlich Bayerischen Akademie der Wissenschaften. Munich. 4: 142.

Simmons, M.P, \& Ochoterena, H. 2000. Gaps as Characters in Sequence-Based Phylogenetic Analyses. Syst.

Biol. 49: 369-381.

Soh, W.K., von Sternburg, M., Hodkinson, T.R. \& Parnell J.A. 2014. Buxus sirindhorniana sp. nov. (Buxaceae), a bicarpellate species from Thailand. Nordic Journal of Botany. 32: 452-458.

Soh, W.K. \& Parnell J.A. 2018. Buxaceae. Flora of Thailand. 14: 9-13.

Stamatakis A. 2014. RAxML version 8: a tool for phylogenetic analysis and post-analysis of large phylogenies, Bioinformatics. 30: 1312-1313.

Standley, P.C. 1936. Studies of American plants. VI. Field Museum of Natural History, Chicago.

Takahashi, M., Herendeen, P.S. \& Xiao, X. 2017. Two early eudicot fossil flowers from the Kamikitaba assemblage (Coniacian, Late Cretaceous) in northeastern Japan. Journal of Plant Research 130: 809-826. 
Takhtajan, A.L. 2009. Flowering Plants. Springer, New York.

Thouars, A.1804. Histoire des Végétaux Recueillis sur les Iles de France, la Réunion (Bourbon) et Madagascar. Huzard, Paris.

Torrez V. \& Jørgensen, P.M. 2010. Styloceras connatum (Buxaceae), una nueva especie de Bolivia. Novon. 20: 363-366.

Turland, N. J., Wiersema, J. H., Barrie, F. R., Greuter, W., Hawksworth, D. L., Herendeen, P. S., Knapp, S., Kusber, W.-H., Li, D.-Z., Marhold, K., May, T. W., McNeill, J., Monro, A. M., Prado, J., Price, M. J. \& Smith, G. F. (eds.) 2018. International Code of Nomenclature for algae, fungi, and plants (Shenzhen Code) adopted by the Nineteenth International Botanical Congress Shenzhen, China, July 2017. Regnum Vegetabile 159. Koeltz Botanical Books, Glashütten

Ulloa, C.U., Acevedo-Rodríguez, P., Beck, S., Belgrano, M.J., Bernal, R., Berry, P.E., Brako, L., Celis, M., Davidse, G., Forzza, R.C. \& Gradstein, S.R. 2017. An integrated assessment of the vascular plant species of the Americas. Science. 358(6370): 1614-1617.

van Laere K., Hermans D., Leus L. \& van Huylenbroeck J. 2011. Genetic relationships in European and Asiatic Buxus species based on AFLP markers, genome sizes and chromosome numbers. Plant Syst. Evol. 293: 1-11. van Tieghem, P. 1897. Sur les Buxacees. Ann. Sci. Nat. VIII. Bot. 5: 290-301.

von Balthazar, M. \& Endress, P.K. 2002a. Development of inflorescences and flowers in Buxaceae and the problem of perianth interpretation. Int. J. Plant Sci. 163: 847-876.

von Balthazar, M. \& Endress, P.K. 2002b. Reproductive structures and systematics of Buxaceae. Bot. J. Linn. Soc.. 140: 193-228.

von Balthazar, M., Endress, P.K. \& Qiu, Y.L. 2000. Phylogenetic relationships in Buxaceae based on nuclear internal transcribed spacers and plastid $n d h$ F sequences. Int. J. Plant Sci. 161: 785-792. 
von Balthazar, M., Schatz, G.E. \& Endress, P.K. 2003. Female flowers and inflorescences of Didymelaceae.

Plant Syst. Evol. 237: 199-208.

Worberg, A., Quandt, D., Barniske, A.M., Löhne, C., Hilu, K.W., Borsch, T. 2007. Phylogeny of basal eudicots: insights from non-coding and rapidly evolving DNA. Organisms Diversity \& Evolution. 7: 55-77. 


\section{Figure legends}

Figure 1. The map of the world which shows the geographic distribution of the group.

Figure 2. Comparison of the topologies resulted from the phylogenetic analyses of CP (plastid markers) supermatrix: Bayesian (left) and RAxML (right). Each triangle is the result of concatenation applied to the branches of the corresponding phylogenetic trees.

Figure 3. Comparison of the topologies resulted from the phylogenetic analyses of OI ( $t r n \mathrm{~L}, r b c \mathrm{~L}$ and ITS2) supermatrix: Bayesian (left) and RAxML (right). Each triangle is the result of concatenation applied to the branches of the corresponding phylogenetic trees.

Figure 4. The Bayesian phylogenetic tree obtained from CP (plastid markers) supermatrix, node labels denote the BPP (in \%). See the text for the explanation of clade names.

Figure 5. The Bayesian phylogenetic tree obtained from OI ( $t r n \mathrm{~L}, r b c \mathrm{~L}$ and ITS2) supermatrix, node labels denote the BPP (in \%), stars* designate species sequenced for the first time. See the text for the explanation of clade names.

Figure 6. The maximum likelihood (RAxML) tree obtained from the "full ITS" matrix, node labels denote the bootstrap support, stars* designate species sequenced for the first time.

Figure 7. Didymeles toamasinae, the holotype (MO).

Figure 8. Sealya conzattii, left to right: branch, inflorescence, crotonoid pollen grains (photo credit to Jose Panero, Texas). This plant was also used for DNA extraction. 


\section{Support materials}

Support Table 1. Working classification of Buxaceae.

Support Table 2. Vouchers of Buxaceae samples.

Support Table 3. GenBank accession numbers of Buxaceae samples sequenced for this study.

Support Table 4. GenBank accession numbers of Buxaceae sequences of external origin used in this study. 


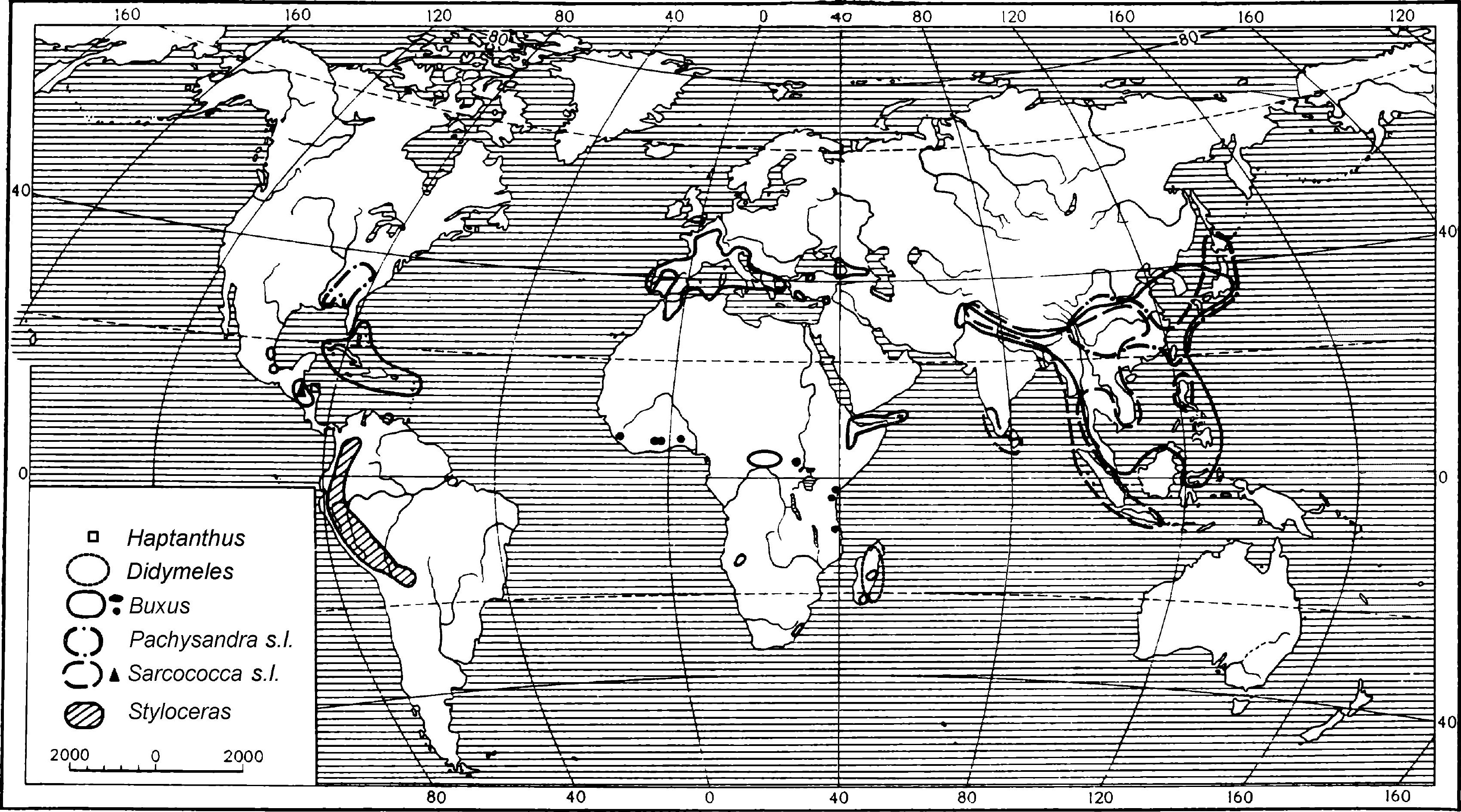



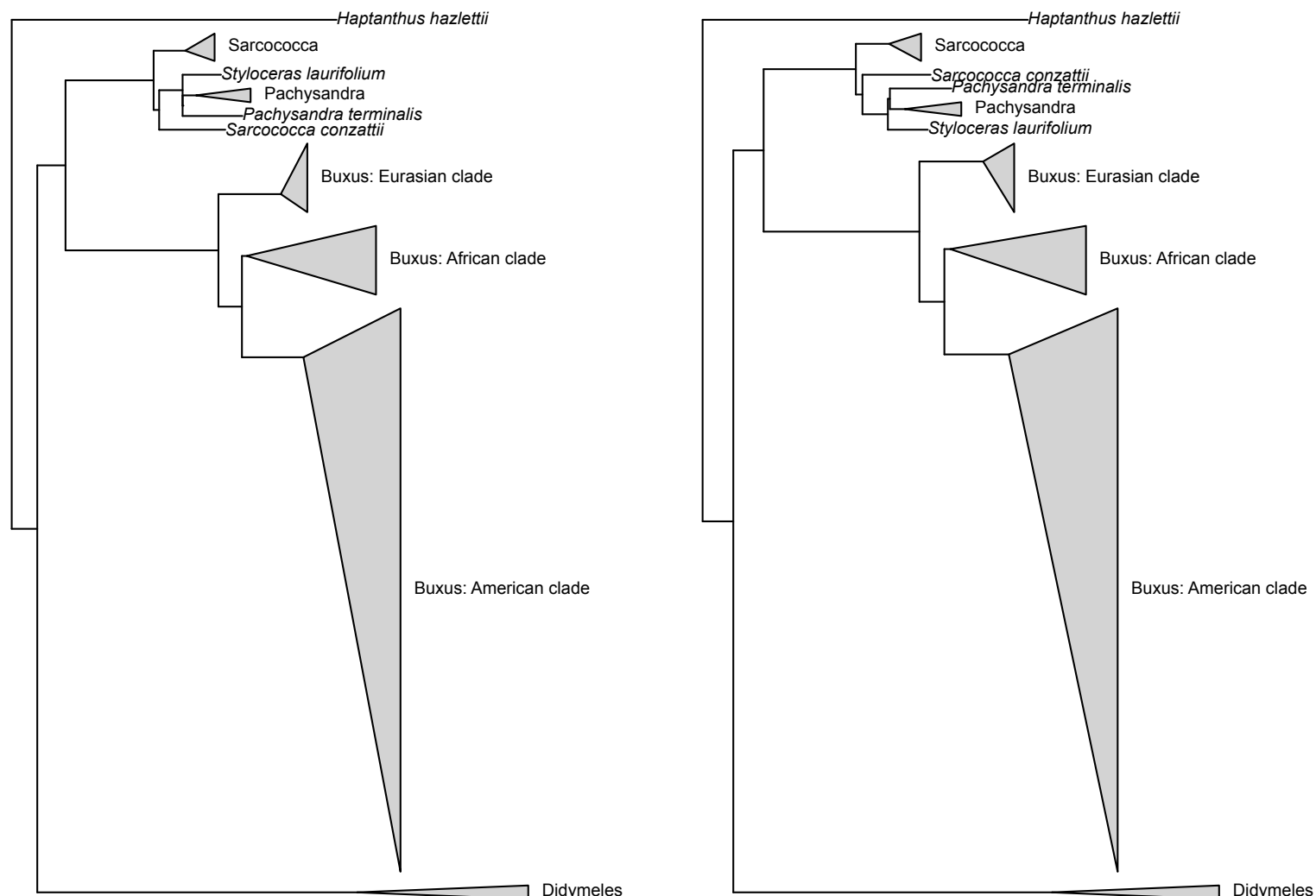

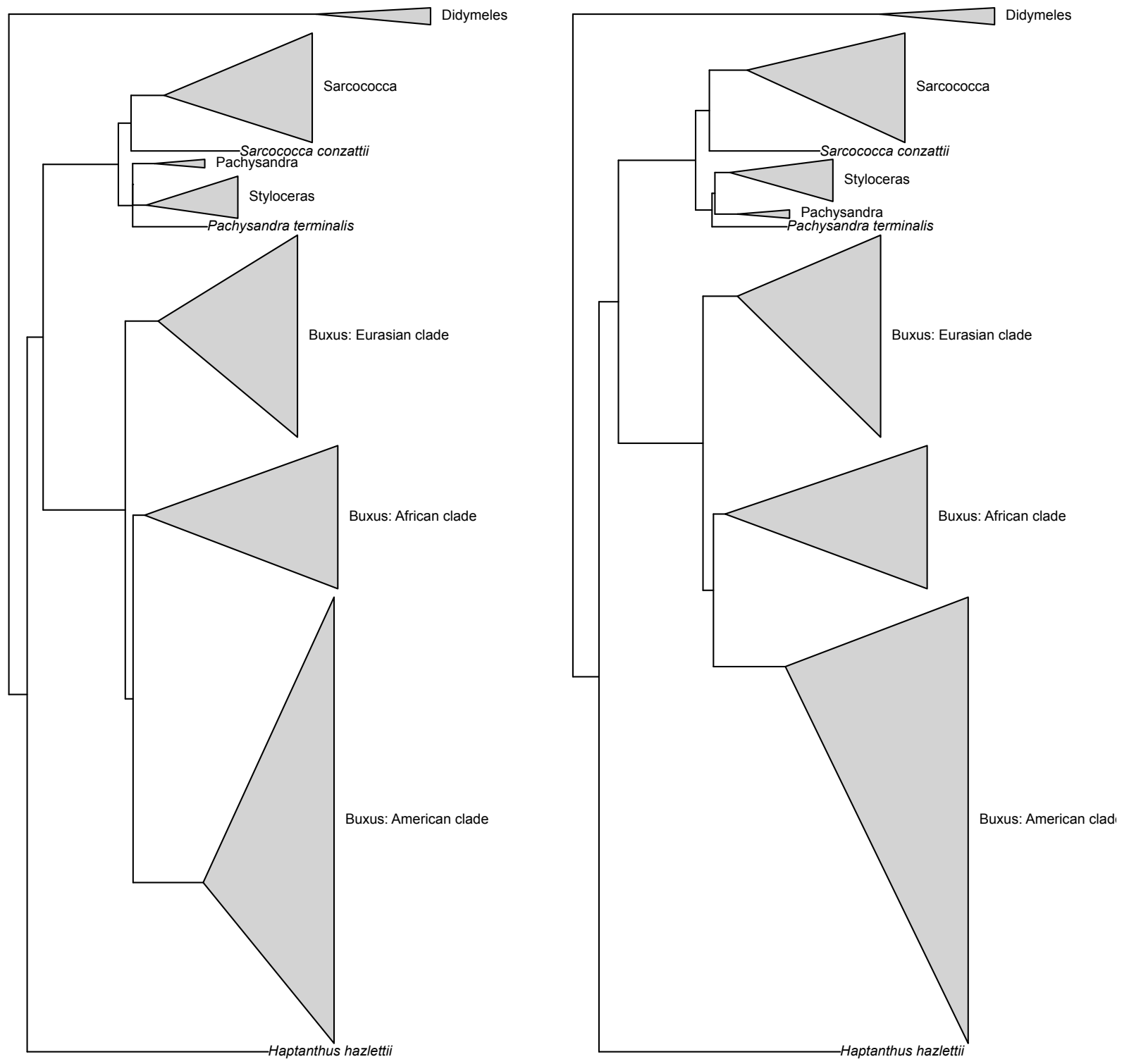


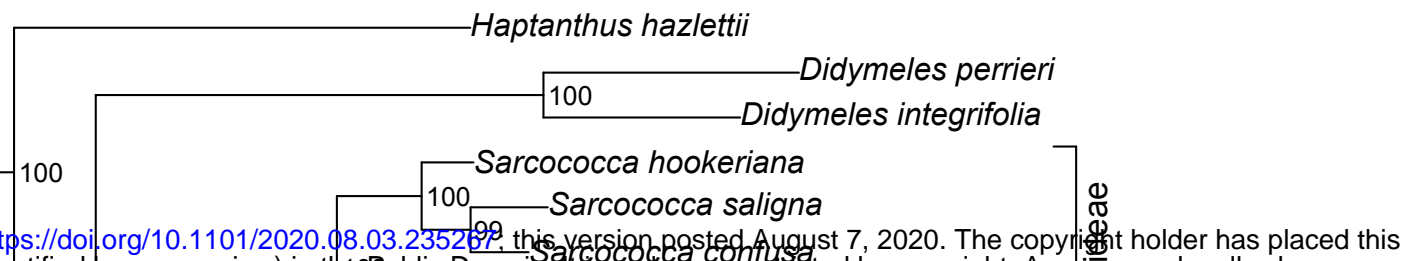

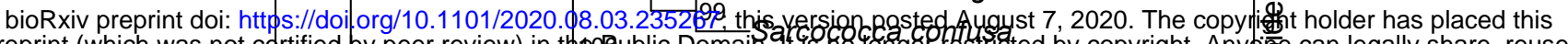
preprint (which was not certified py peer review) in thiofublic Domain.

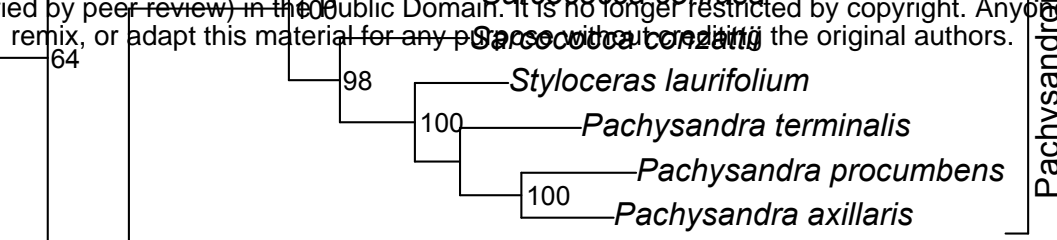

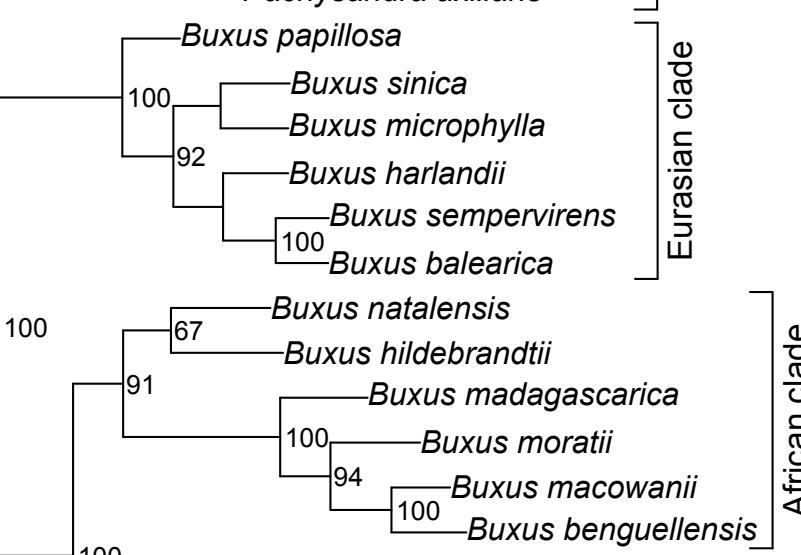

100

Buxus mexicana

-Buxus brevipes

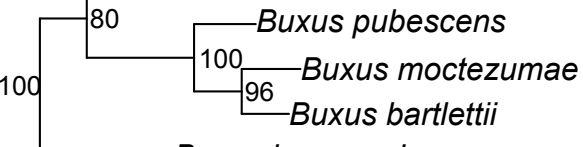

Buxus jaucoensis $79 \begin{array}{r}97 \quad \text { Buxus gonoclada } \\ \text { Buxus cristalensis } \\ \text { Buxus serpentinicola }\end{array}$

${ }_{1}^{100} \quad 62$ Buxus triptera

100 


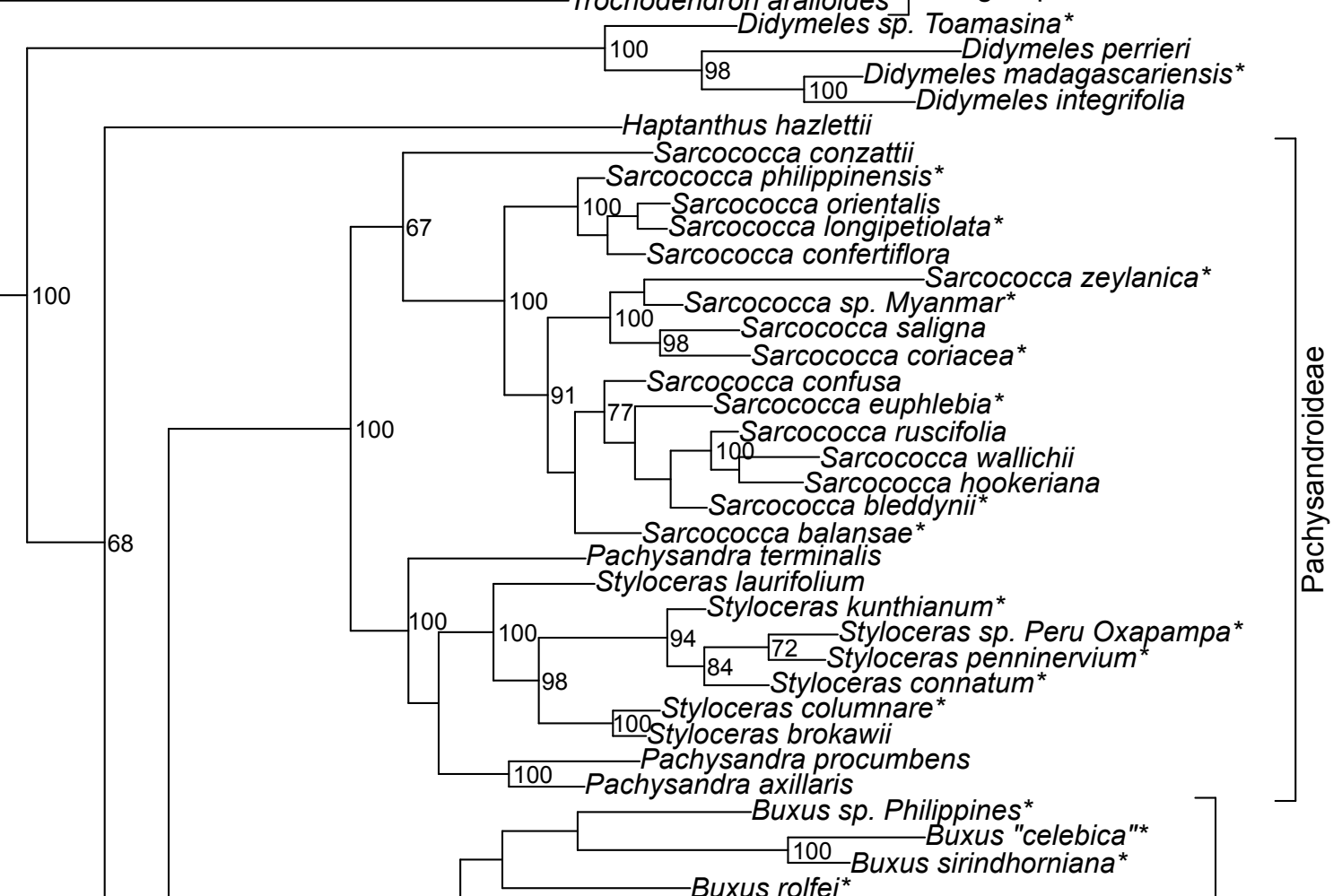

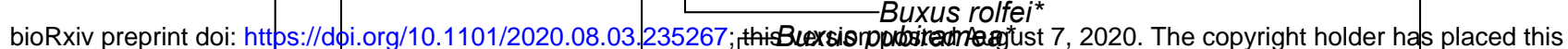

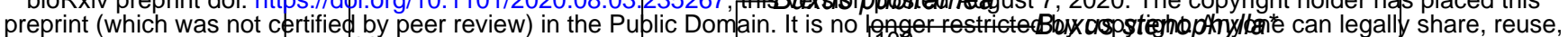

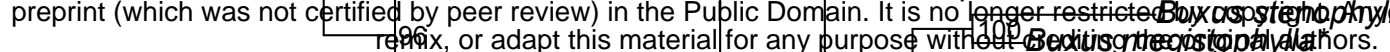

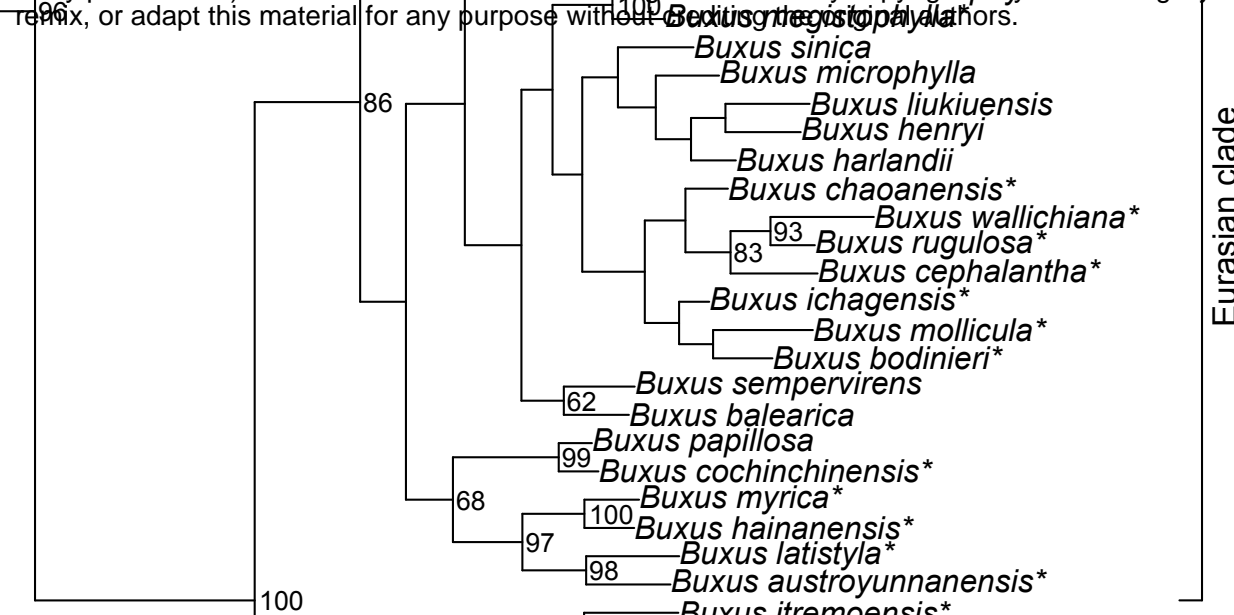

100

Buxus austroyunnane

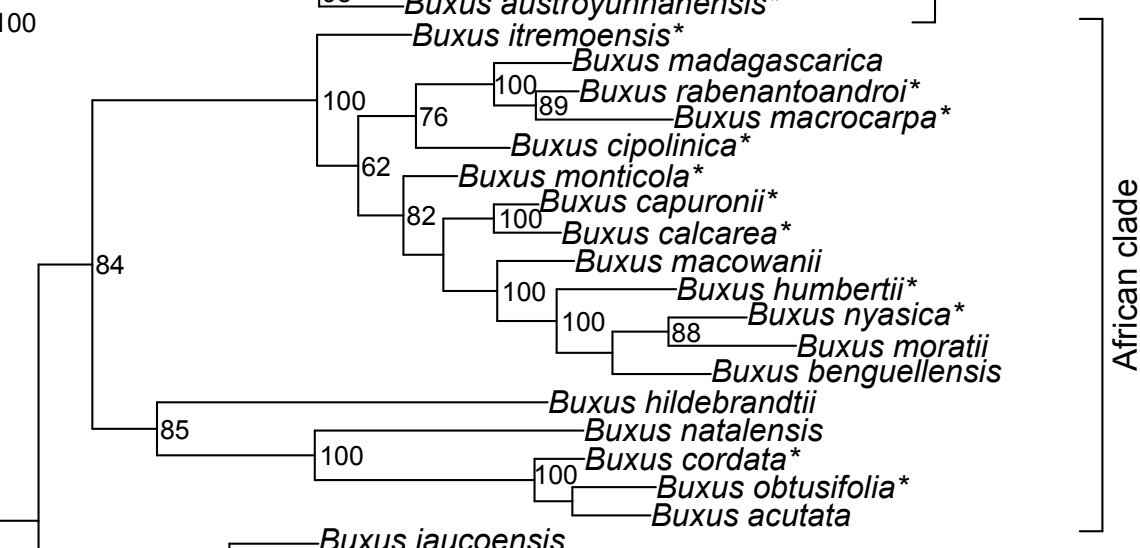

100
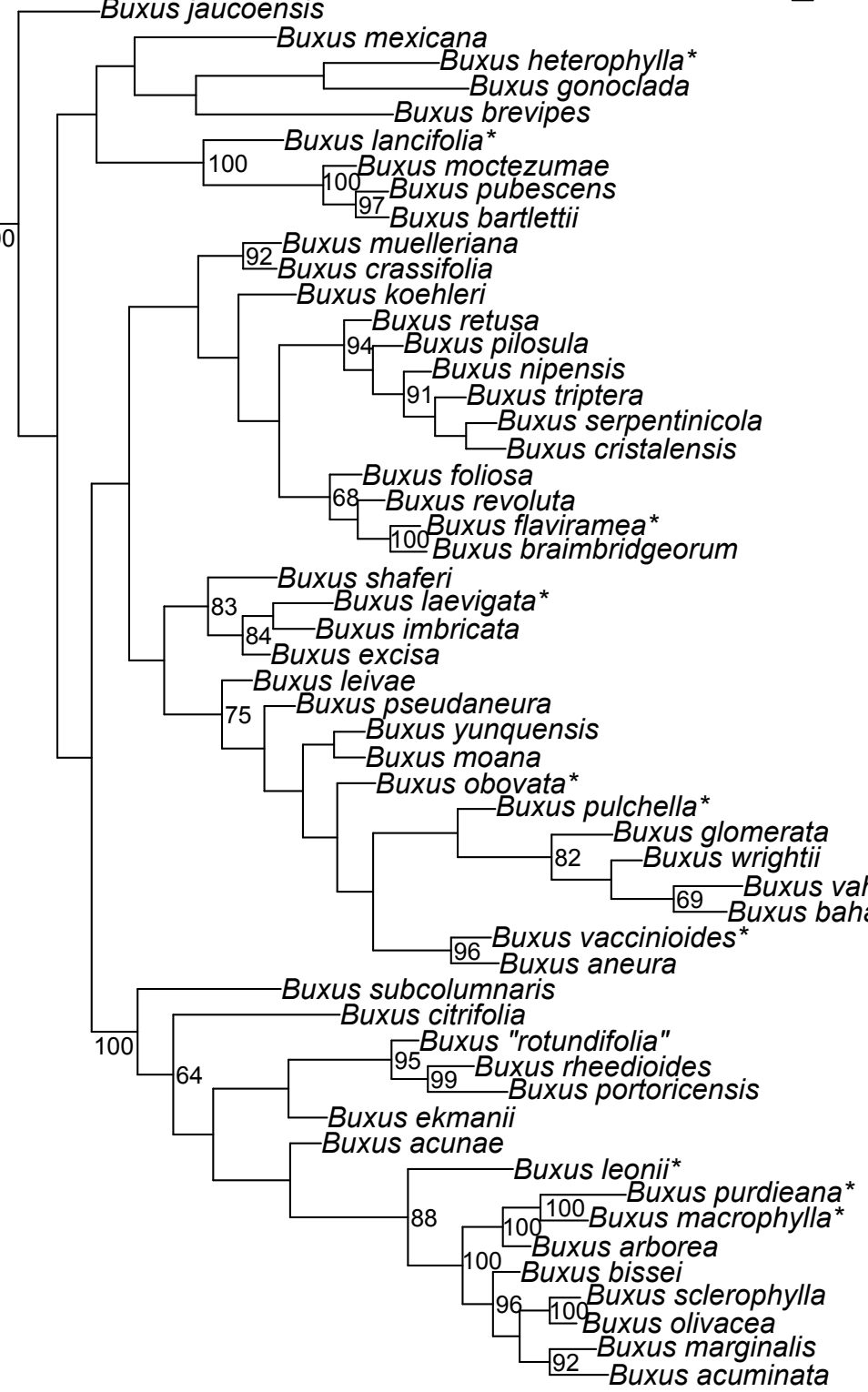


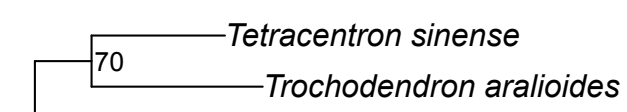

Daphniphyllum macropodum

Didymeles perrieri

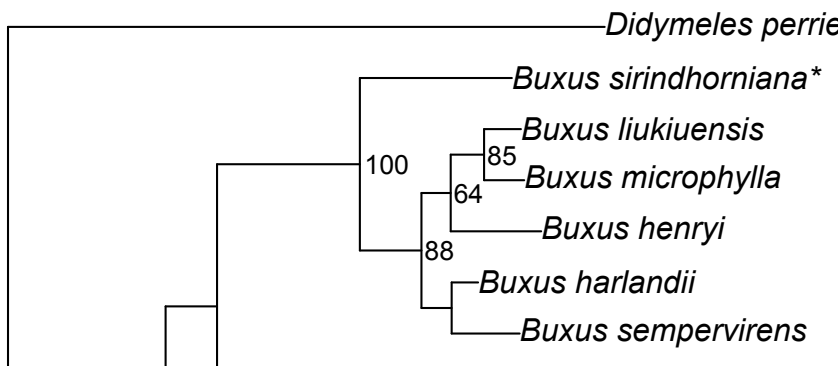

70

100

77

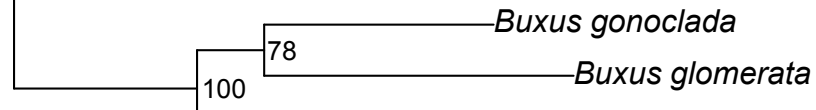

Buxus citrifolia

100

Buxus natalensis

Buxus acutata

Pachysandra procumbens

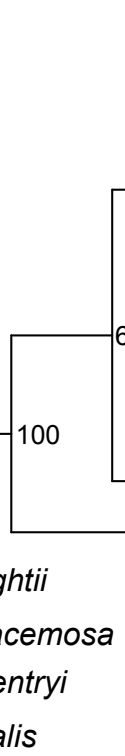

94

Pachysandra axillaris

71

69

80

5 Sarcococca wallichii

98

Sarcococca saligna

$97 \quad-S a r c o c o c c a$ hookeriana

78 -Sarcococca ruscifolia

100 LSarcococca bleddynii*

-Sarcococca confertiflora

Styloceras brokawi

Pachysandra terminalis

Sarcococca conzattii

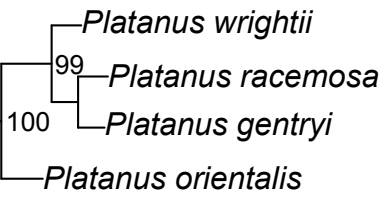




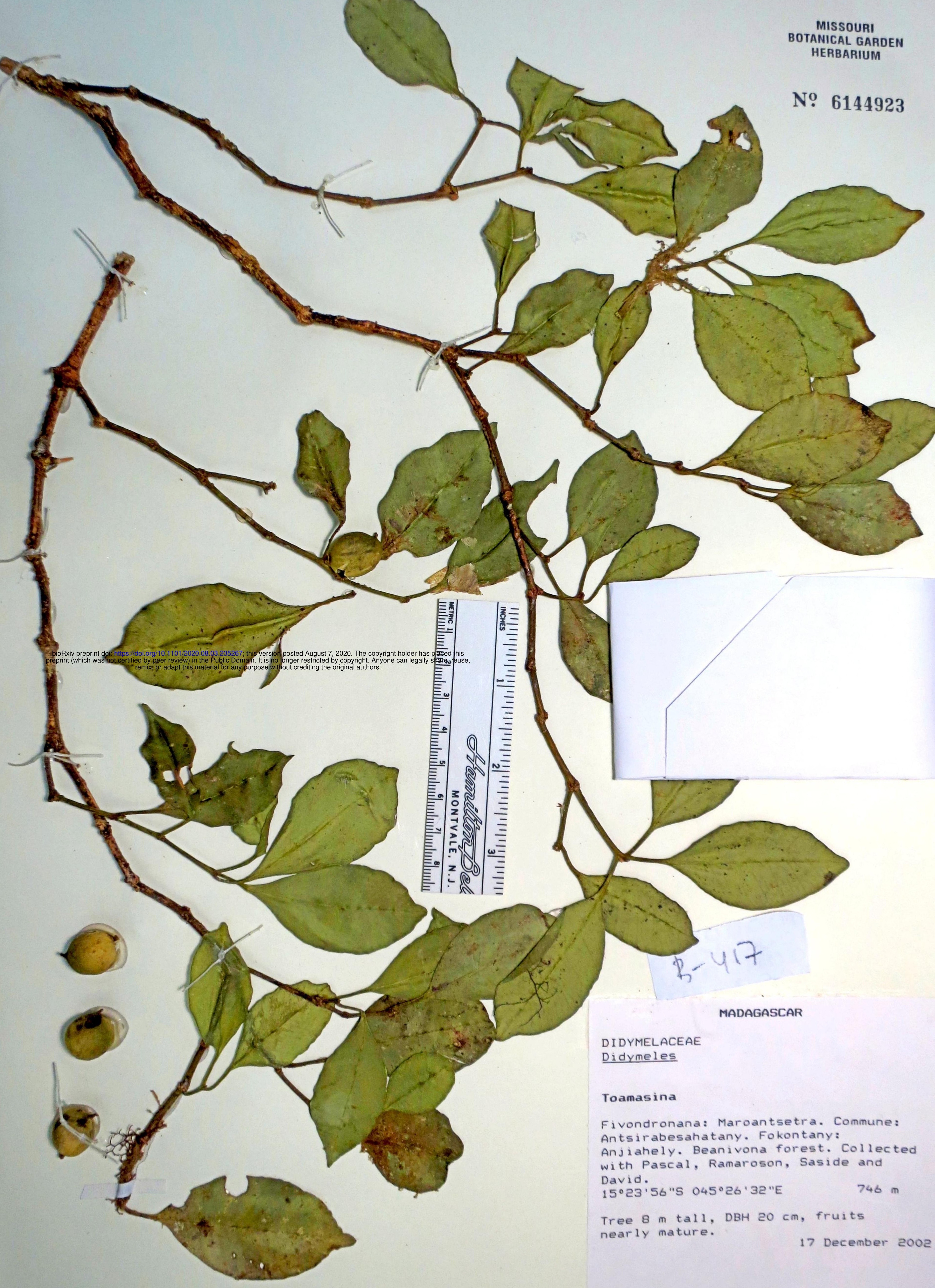

P. Antilahimena et al. 1529

15.16 MISSOURI BOTANICAL GARDEN HERBARIUM (MO) 


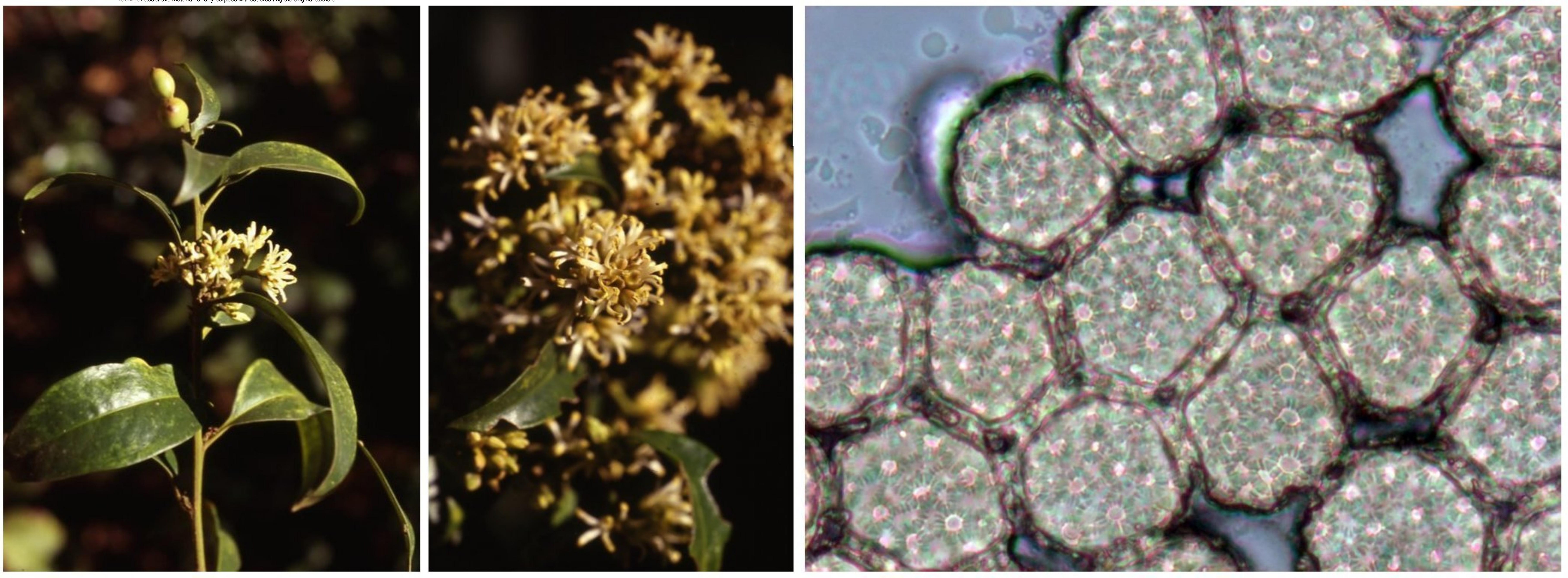




\title{
Buxaceae Dumort.
}

Working classification

\author{
Alexey Shipunov, \\ Aaron Floden
}

$2020-03-24$

\section{Familia 1. Buxaceae Dumort.}

Subfamilia Didymeloideae Floden \& Shipunov, subfam.nov.

Genus 1. Didymeles Thouars, stat.m. ${ }^{1}$

1(1). Didymeles integrifolia J.St.-Hil.

2(2). Didymeles madagascariensis Willd., stat.m. ${ }^{2}$

3(3). Didymeles perrieri Leandri

4(4). Didymeles toamasinae Floden \& Shipunov, sp.nov.

\section{Subfamilia Haptanthoideae Floden \& Shipunov,} subfam.nov.

Genus 2. HaPtanthus Goldberg \& C.Nelson stat.m. ${ }^{3}$ 1(5). Haptanthus hazlettii Goldberg \& C.Nelson

\section{Subfamilia Buxoideae Beilschm.}

Genus 3. Buxus L.

\section{Subgenus Buxus ${ }^{4}$}

1(6). Buxus austroyunnanensis Hatus.

2(7). Buxus balearica Lam. ${ }^{5}$

3(8). Buxus bodinieri H.Lév.

4(9). Buxus chaoanensis H.G.Ye

5(10). Buxus cochinchinensis Pierre ex Gagnep. ${ }^{6}$

\footnotetext{
${ }^{1}$ Sometimes in Didymelaceae Leandri.

${ }^{2}$ Didymeles excelsa Baill.

${ }^{3}$ Sometimes in Haptanthaceae C.Nelson.

${ }^{4}$ Eubuxus Baill.

${ }^{5}$ Buxus longifolia Boiss.

${ }^{6}$ Buxus holttumiana Hatus.
} 
6(11). Buxus fortunei Carruth.

7(12). Buxus hainanensis Merr.

8(13). Buxus harlandii Hance ${ }^{7}$

9(14). Buxus hebecarpa Hatus.

10(15). Buxus henryi Mayr

11(16). Buxus ichagensis Hatus.

12(17). Buxus latistyla Gagnep.

13(18). Buxus linearifolia M.Cheng

14(19). Buxus liukiuensis (Makino) Makino

15(20). Buxus loheri Merr.

16(21). Buxus malayana Ridl.

17(22). Buxus megistophylla H.Lév.

18(23). Buxus microphylla Siebold \& Zucc. ${ }^{8}$

19(24). Buxus mollicula W.W.Sm.

20(25). Buxus myrica H.Lév.

21(26). Buxus pachyphylla Merr.

22(27). Buxus papillosa C.K.Schneid.

23(28). Buxus pubifolia Merr.

24(29). Buxus pubiramea Merr. \& Chun

25(30). Buxus rivularis Merr.

26(31). Buxus rolfei S.Vidal $^{9}$

27(32). Buxus rugulosa Hatus.

28(33). Buxus rupicola Ridl.

29(34). Buxus sempervirens L. ${ }^{10}$

30(35). Buxus sinica (Rehder \& E.H.Wilson) M.Cheng ${ }^{11}$

31(36). Buxus sirindhorniana W.K.Soh \& al.

32(37). Buxus stenophylla Hance

33(38). Buxus wallichiana Baill.

Subgenus Notobuxus (Oliv.) Floden \& Shipunov, subg.nov.

34(39). Buxus acutata Friis ${ }^{12}$

35(40). Buxus benguellensis Gilg ${ }^{13}$

36(41). Buxus calcarea G.E.Schatz \& Lowry

37(42). Buxus capuronii G.E.Schatz \& Lowry

38(43). Buxus cipolinica Lowry \& G.E.Schatz

39(44). Buxus cordata (Radcl.-Sm.) Friis ${ }^{14}$

\footnotetext{
${ }^{7}$ Buxus cephalantha H.Lév. \& Vaniot

${ }^{8}$ Buxus riparia (Makino) Makino

${ }^{9}$ Buxus philippinensis Rolfe, nom.nud.

${ }^{10}$ Buxus colchica Pojark.; Buxus hyrcana Pojark.

${ }^{11}$ Buxus intermedia Kaneh.

${ }^{12}$ Notobuxus acuminata (Gilg.) Hutch.

${ }^{13}$ Notobuxus benguellensis (Gilg) E.Phillips; Buxus hirta (Hutch.) Mathou

${ }^{14}$ Notobuxus cordata Radcl.-Sm.
} 
40(45). Buxus hildebrandtii Baill. ${ }^{15}$

41(46). Buxus humbertii G.E.Schatz \& Lowry

42(47). Buxus itremoensis G.E.Schatz \& Lowry

43(48). Buxus lisowskii Bamps \& Malaisse

44(49). Buxus macowanii Oliv. ${ }^{16}$

45(50). Buxus macrocarpa Capuron

46(51). Buxus madagascarica Baill. ${ }^{17}$

47(52). Buxus monticola G.E.Schatz \& Lowry

48(53). Buxus moratii G.E.Schatz \& Lowry

49(54). Buxus natalensis (Oliv.) Hutch. ${ }^{18}$

50(55). Buxus nyasica Hutch. ${ }^{19}$

51(56). Buxus obtusifolia (Mildbr.) Hutch. ${ }^{20}$

52(57). Buxus rabenantoandroi G.E.Schatz \& Lowry ${ }^{21}$

Subgenus Tricera (Swartz ex Schreb.) Floden \& Shipunov, subg.nov.

53(58). Buxus acuminata (Griseb.) Müll.Arg. ${ }^{22}$

54(59). Buxus acunae Borhidi \& O.Muñiz

55(60). Buxus aneura Urb.

56(61). Buxus arborea Proctor

57(62). Buxus bahamensis Baker ${ }^{23}$

58(63). Buxus baracoensis Borhidi \& O.Muñiz ${ }^{24}$

59(64). Buxus bartlettii Standl.

60(65). Buxus bissei Eg.Köhler

61(66). Buxus braimbridgeorum Eg.Köhler

62(67). Buxus brevipes (Müll.Arg.) Urb. ${ }^{25}$

63(68). Buxus citrifolia (Willd.) Spreng. ${ }^{26}$

64(69). Buxus crassifolia (Britton) Urb. ${ }^{27}$

65(70). Buxus cristalensis Eg. Köhler \& P.A.González

66(71). Buxus cubana (A.Rich.) Baill. ${ }^{28}$

67(72). Buxus cyclophylla Floden \& Shipunov, nom.nov. ${ }^{29}$

\footnotetext{
${ }^{15}$ Buxus calophylla Pax; Buxanthus hildebrantii Tiegh.; Buxus pedicellata (Tiegh.) Hutch.; Buxanthus pedicellatus Tiegh.

${ }^{16}$ Buxella macowanii Tiegh.; Notobuxus macowanii (Oliv.) E. Phillips

${ }^{17}$ Buxella madagascarica Tiegh.; Notobuxus madagascarica (Baill.) E. Phillips

${ }^{18}$ Notobuxus natalensis Oliv.

${ }^{19}$ Notobuxus nyasica (Hutch.) E.Phillips

${ }^{20}$ Notobuxus obtusifolia Mildbr.

${ }^{21}$ Buxus angustifolia G.E.Schatz \& Lowry

22 Tricera acuminata Griseb.

${ }^{23}$ Tricera bahamensis (Baker) Britton

${ }^{24}$ Buxus shaferi (Britton) Urb. p.p. sensu Eg.Köhler

25 Tricera brevipes Britton

${ }^{26}$ Tricera citrifolia Willd.

27 Tricera crassifolia Britton.

${ }^{28}$ Tricera cubana A.Rich.

${ }^{29}$ Tricera rotundifolia Britton; Buxus rotundifolia (Britton) Mathou, nom.illeg., non Buxus rotundifolia hort. ex K.Koch
} 
68(73). Buxus ekmanii Urb.

69(74). Buxus excisa Urb.

70(75). Buxus flaviramea (Britton) Mathou ${ }^{30}$

71(76). Buxus foliosa (Britton) Urb. ${ }^{31}$

72(77). Buxus glomerata (Griseb.) Müll.Arg. ${ }^{32}$

73(78). Buxus gonoclada (Griseb.) Müll.Arg. ${ }^{33}$

74(79). Buxus heterophylla Urb. ${ }^{34}$

75(80). Buxus historica Borhidi \& O.Muñiz ${ }^{35}$

76(81). Buxus imbricata Urb.

77(82). Buxus jaucoensis Eg.Köhler

78(83). Buxus koehleri P.A.González \& Borsch

79(84). Buxus laevigata Spreng.

80(85). Buxus lancifolia Brandegee

81(86). Buxus leivae Eg.Köhler

82(87). Buxus leonii (Britton) Mathou ${ }^{36}$

83(88). Buxus macrophylla (Britton) Fawc. \& Rendle ${ }^{37}$

84(89). Buxus marginalis (Britton) Urb. ${ }^{38}$

85(90). Buxus mexicana Brandegee

86(91). Buxus moana Alain

87(92). Buxus moctezumae Eg.Köhler, R.Fernald \&

Zamudio

88(93). Buxus muelleriana Urb. ${ }^{39}$

89(94). Buxus nipensis Eg. Köhler \& P.A.González

90(95). Buxus obovata Urb. ${ }^{40}$

91(96). Buxus olivacea Urb.

92(97). Buxus pilosula Urb.

93(98). Buxus portoricensis Alain

94(99). Buxus pseudaneura Eg.Köhler

95(100). Buxus pubescens Greenm.

96(101). Buxus pulchella Baill.

97(102). Buxus purdieana Baill.

98(103). Buxus retusa (Griseb.) Müll.Arg. ${ }^{41}$

99(104). Buxus revoluta (Britton) Mathou ${ }^{42}$

\footnotetext{
${ }^{30}$ Tricera flaviramea Britton; Buxus gonoclada (Griseb.) Müll.Arg. p.p. sensu Eg.Köhler

31 Tricera foliosa Britton

32 Tricera glomerata Griseb.

33 Tricera gonoclada Griseb.

${ }^{34}$ Buxus gonoclada (Griseb.) Müll.Arg. p.p. sensu Eg.Köhler

${ }^{35}$ Buxus retusa (Griseb.) Müll.Arg. p.p. sensu Eg.Köhler

${ }^{36}$ Tricera leonii Britton; Buxus wrightii subsp. leonii (Britton) Eg.Köhler

${ }^{37}$ Tricera macrophylla Britton

38 Tricera marginalis Britton

${ }^{39}$ Tricera muelleriana Britton

${ }^{40}$ Buxus shaferi (Britton) Urb. p.p. sensu Eg.Köhler

${ }^{41}$ Tricera retusa Griseb.

${ }^{42}$ Tricera revoluta Britton
} 
100(105). Buxus rheedioides Urb.

101(106). Buxus sclerophylla Eg.Köhler

102(107). Buxus serpentinicola Eg.Köhler

103(108). Buxus shaferi (Britton) Urb. ${ }^{43}$

104(109). Buxus subcolumnaris Müll.Arg.

105(110). Buxus triptera Eg.Köhler

106(111). Buxus vaccinioides (Britton) Urb. ${ }^{44}$

107(112). Buxus vahlii Baill.

108(113). Buxus wrightii Müll.Arg. ${ }^{45}$

109(114). Buxus yunquensis Eg.Köhler

\section{Subfamilia Pachysandroideae Record \& Garratt}

\section{Genus 4. SARCOCOCCA Lindl.}

1(115). Sarcococca balansae Gagnep.

2(116). Sarcococca bleddynii J.M.H.Shaw \& N. van Du

3(117). Sarcococca confertiflora Sealy

4(118). Sarcococca confusa Sealy

5(119). Sarcococca coriacea Sweet $^{46}$

6(120). Sarcococca hookeriana Baill. ${ }^{47}$

7(121). Sarcococca euphlebia Merrill

8(122). Sarcococca longifolia M. Cheng \& K.F. Wu

9(123). Sarcococca longipetiolata M. Cheng

10(124). Sarcococca orientalis C.Y. Wu

11(125). Sarcococca philippinensis Stapf ex Sealy

12(126). Sarcococca ruscifolia Stapf $^{48}$

13(127). Sarcococca saligna (D.Don.) Müll.Arg. ${ }^{49}$

14(128). Sarcococca wallichii Stapf

15(129). Sarcococca zeylanica Baill. ${ }^{50}$

16(130). Sarcococca zollingeri Baill.

Genus 5. Sealya Floden \& Shipunov, gen.nov.

1(131). Sealya conzattii (Standl). Floden \& Shipunov, comb.nov. ${ }^{51}$

\footnotetext{
${ }^{43}$ Tricera shaferi Britton

${ }^{44}$ Tricera vaccinioides Britton

${ }^{45}$ Tricera microphylla Griseb.

${ }^{46}$ Sarcococca nepalensis Royle; Sarcococca pruniformis Lindl. p.p.; Sarcococca tonkinensis Gagnep.; Sarcococca trinervia Wight; Sarcococca vagans Stapf

${ }^{47}$ Sarcococca humilis Stapf

${ }^{48}$ Sarcococca pauciflora C.Y.Wu

${ }^{49}$ Sarcococca pruniformis Lindl. p.p.

${ }^{50}$ Sarcococca brevifolia (Muell. Arg.) Stapf ex Gamble

${ }^{51}$ Sarcococca conzattii (Standl.) I.M. Johnst.; Buxus conzattii Standl.
} 
Genus 6. PAChysandra Michx.

1(132). Pachysandra terminalis Siebold \& Zucc. sed.m.

2(133). Pachysandra axillaris Franch. ${ }^{52}$

3(134). Pachysandra procumbens Michx.

\section{Genus 7. Styloceras Kunth ex A.Juss.}

1(135). Styloceras brokawii A.H.Gentry \& R.B.Foster 2(136). Styloceras columnare Müll.Arg.

3(137). Styloceras connatum Torrez \& P. Jørg. 4(138). Styloceras kunthianum A. Juss.

5(139). Styloceras laurifolium (Willd.) Kunth

6(140). Styloceras penninervium A.H. Gentry \& G.A. Aymard

\footnotetext{
${ }^{52}$ Pachysandra stylosa Dunn
} 


\section{Taxon name}

Buxus acuminata

Buxus acutata

Buxus acutata

Buxus aneura

Buxus arborea

Buxus austroyunnanensis

Buxus bahamensis

Buxus bahamensis

Buxus balearica

Buxus bartlettii

Buxus benguellensis

Buxus bissei

Buxus bodinieri

Buxus braimbridgeorum

Buxus braimbridgeorum

Buxus brevipes

Buxus brevipes

Buxus calcarea

Buxus capuronii

Buxus cephalantha shantouensis

Buxus chaoanensis

Buxus cipolinica

Buxus cipolinica

Buxus citrifolia

Buxus cochinchinensis

Buxus cochinchinensis

Buxus cochinchinensis

Buxus cochinchinensis

Buxus cordata

Buxus cordata

Buxus cordata

Buxus crassifolia

Buxus excisa
Sample ID Voucher (herbarium ID or similar)

B-201 Jongkind 9408 (PRE)

B-420 Breteler 13756 (MO-5759128)

B-421 De Wilde 9408 (MO-4310785)

B-118 Ekman 15176 (NY)

B-101 Gentry 28311 (NY-01381367)

B-722 Zhou 619 (CAS-1153485)

B-1601 Correll 43786 (BRIT)

B-635 Webster 10423 (US-2432374)

B-622 Kennedy 865D (US-1862163)

B-716 Wendt 3672 (CAS-732187)

B-202 PRE-854763.0

B-510 Shafer $4277(\mathrm{HUH})$

B-1819 PE-01981551

B-103 Shafer 8151 (NY-02150567)

B-125 Shafer 8151 (NY-02150594)

B-122 Acuna 17252 (NY-02150575)

B-634 Brother Alain 2305 (US-2284282)

B-426 Andriamihajarivo 507 (MO-6298213)

B-425 Capuron 24212-SF (MO-5730160)

B-1807 IBSC-0754341

B-1808 IBSC-0345394

B-205 Birkinshaw 1399 (PRE)

B-206 Birkinshaw 1399 (PRE)

B-623 Bordenave 8253 (US-3523221)

B-1818 Larsen 31272 (PE-00044005)

B-1902 Shimizu 7957 (TI)

B-621 Pot 2488 (US-2589403)

B-809 Soejarto 14857 (F-2300811)

B-1602 Mwangoka 1274 (BRIT)

B-200 Mwasumbi 2505 (PRE)

B-422 Mwangoka 1274 (MO-5584102)

B-100 Sattler C732002 (NY-01381373)

B-114 Ekman 3809 (NY) 


\begin{tabular}{|c|c|c|}
\hline Buxus flaviramea & B-107 & Greuter s.n. (NY-01381374) \\
\hline Buxus foliosa & B-106 & Shafer 4073 (NY-02150593) \\
\hline Buxus glomerata & B-631 & Garcia 3618 (US-3325282) \\
\hline Buxus glomerata & B-711 & Ekman 9477 (UC-996186) \\
\hline Buxus gonoclada & B-632 & Morton 8778 (US-2284934) \\
\hline Buxus gonoclada & B-803 & Ekman 18585 (F-1474623) \\
\hline Buxus hainanensis & B-717 & Lau 5437 (CAS-728942) \\
\hline Buxus harlandii & B-620 & Hu 6560 (US-2697068) \\
\hline Buxus henryi & B-718 & Xiao 3357 (CAS-1148720) \\
\hline Buxus heterophylla & B-119 & Ekman 7555 (NY) \\
\hline Buxus hildebrandtii & B-808 & Burger 2978 (F-1632789) \\
\hline Buxus humbertii & B-409 & Ratovoson 1539 (MO-6426683) \\
\hline Buxus ichagensis & B-1815 & PE-00044079 \\
\hline Buxus ichagensis & B-1816 & PE-00044075 \\
\hline Buxus imbricata & B-710 & Ekman 15979 (UC-996190) \\
\hline Buxus itremoensis & B-407 & Shatz 3980 (MO-5814397) \\
\hline Buxus itremoensis & B-408 & Randrianaivo 154 (MO-5206210) \\
\hline Buxus laevigata & B-123 & Harris 10755 (NY-02150672) \\
\hline Buxus lancifolia & B-713b & Purpus 5304 (UC-155266) \\
\hline Buxus latistyla & B-1810 & IBSC-0705548 \\
\hline Buxus latistyla & B-1814 & PE-00044093 \\
\hline Buxus leonii & $B-121$ & Brother Leon 4874 (NY) \\
\hline Buxus linearifolia & B-1809 & IBSC-0345454 \\
\hline Buxus liukiuensis & B-619 & Elliott 609 (US-2594126) \\
\hline Buxus macowanii & B-207 & No voucher, cultivated, photo in repository \\
\hline Buxus macowanii & B-612 & Hardy 5337 (US-2999716) \\
\hline Buxus macrocarpa & B-406 & Rabe 83 (MO-6574040) \\
\hline Buxus macrophylla & B-630 & Proctor 11819 (US-2585569) \\
\hline Buxus madagascarica & B-412 & Razakamalala 2653 (MO-6426702) \\
\hline Buxus madagascarica & B-413 & Rabehevitra 1117 (MO-6039950) \\
\hline Buxus madagascarica & B-611 & Rabevohitra 3799 (US-3596205) \\
\hline Buxus marginalis & B-629 & Axelrod 10410 (US-3397787) \\
\hline Buxus megistophylla & B-1901 & Taam $535(\mathrm{TI})$ \\
\hline Buxus mexicana & $B-712 b$ & Purpus 2972 (UC-112959) \\
\hline
\end{tabular}


Buxus mexicana

Buxus microphylla

Buxus microphylla

Buxus moctezumae

Buxus mollicula

Buxus monticola

Buxus monticola

Buxus monticola

Buxus moratii

Buxus moratii

Buxus muelleriana

Buxus myrica

Buxus myrica

Buxus nipensis

Buxus nyasica

Buxus obovata

Buxus obtusifolia

Buxus olivacea

Buxus olivacea

Buxus papillosa

Buxus papillosa

Buxus pilosula

Buxus portoricensis

Buxus pubescens

Buxus pubiramea

Buxus pulchella

Buxus purdieana

Buxus rabenantoandroi

Buxus retusa

Buxus retusa

Buxus revoluta

Buxus rheedioides

Buxus rolfei

Buxus rotundifolia
B-723

B-618

B-704

B-724

B-503

B-112

B-410

B-411

B-418

B-610

B-505

B-616

B-706

B-113

B-204

B-110

B-810

B-709

B-817

B-617

B-705

B-111

B-816

B-636

B-1805

B-109

B-802

B-414

B-105

B-502

B-104

B-117

B-614

B-115
Salinas 7524 (CAS-895786)

Moran 4286 (US-2186325)

Bartholomew 233 (UC-1491018)

Zamudio 11702 (CAS-1027047)

$\mathrm{Hu} 13051$ (HUH)

Razanatsima 123 (NY)

Capuron 23522-SF (MO-5727647)

Razanatsima 123 (MO-6053339)

De Block 2209 (MO-6301378)

Gillespie 4112 (US-3225197)

Brother Alain 5451 (HUH)

Wang 33332 (US-1670146)

Gressitt 1305 (UC-1352900)

Shafer 3219 (NY-02150556)

Chapman 8828 (PRE)

Ekman 15953 (NY-02150588)

Faden 77/647 (F-2155753)

Ekman 15218 (UC-996194)

Ekman 4992 (F-1474625)

Rechinger 29820 (US-2637743)

Rechinger 29820 (UC-1376594)

Brother Leon 19897 (NY-02150633)

Brother Alain 9811 (F-1618398)

Ferris 5676 (US-1269103)

IBSC-0345586

Britton 4150 (NY-02150671)

Harris 8964 (F-212020)

Razakamalala 4530 (MO-6426685)

Abbott 18972 (NY-01381392)

Brother Alain $3668(\mathrm{HUH})$

Berazain s.n. (NY-01381393)

Ekman 15175 (NY)

Larsen 33973 (US-3376317)

Shafer 4114 (NY) 


\begin{tabular}{|c|c|c|}
\hline Buxus rugulosa & B-721 & Boufford 2884 (CAS-1011214) \\
\hline Buxus sempervirens & B-003 & No voucher, cultivated, photo in repository \\
\hline Buxus sempervirens hyrcana & B-302 & No voucher, photo in repository \\
\hline Buxus shaferi & B-627 & Brother Alain 4761 (US-2288281) \\
\hline Buxus sinica & B-720 & Yuan 1086 (CAS-846679) \\
\hline Buxus sirindhorniana & $B-500$ & van de Bult $664(\mathrm{HUH})$ \\
\hline Buxus sp. celebica & B-1817 & PE-00044002 \\
\hline Buxus sp. Philippines & B-506 & Reynoso 14113 (HUH) \\
\hline Buxus stenophylla & B-1903 & Hu 13026 (TI) \\
\hline Buxus subcolumnaris & B-626 & Howard 18878 (US-3001023) \\
\hline Buxus vaccinioides & B-116 & Shafer 4122 (NY) \\
\hline Buxus vaccinioides & B-126 & Shafer 4122 (NY) \\
\hline Buxus vahlii & B-625 & Little 21745 (US-2673754) \\
\hline Buxus vahlii & B-807 & Brother Alain 10722 (F-1618353) \\
\hline Buxus wallichiana & B-615 & Koelz 1831 (US-1605756) \\
\hline Didymeles integrifolia & B-602 & Schatz 2778 (US-3627925) \\
\hline Didymeles madagascariensis & B-601 & Rakotomazala 399 (US-3350972) \\
\hline Didymeles perrieri & B-415 & Razafimandribison 119 (MO-5617933) \\
\hline Didymeles sp. Toamasina & B-417 & Antilahimena 1529 (MO-6144923) \\
\hline Didymeles sp. Toamasina & B-423 & Antilahimena 2497a (MO-6177345) \\
\hline Pachysandra axillaris & B-639 & Hsien 1531 (US-1968483) \\
\hline Pachysandra axillaris & B-703 & Bonati s.n. (UC) \\
\hline Pachysandra axillaris & B-714 & Liu 15428 (CAS-943872) \\
\hline Pachysandra procumbens & B-640 & Kral 34119 (US-2674034) \\
\hline Pachysandra terminalis & B-005 & No voucher, cultivated, photo in repository \\
\hline Sarcococca balansae & B-303 & No voucher, photo in repository \\
\hline Sarcococca balansae & B-649 & How 70661 (US-1675664) \\
\hline Sarcococca balansae & B-811 & How 70661 (F-779258) \\
\hline Sarcococca bleddynii & floden3847 & Floden s.n. (TENN) \\
\hline Sarcococca confusa & B-713a & McClintock s.n. (CAS-582464) \\
\hline Sarcococca conzattii & B-651 & Panero 5574 (US-3661245) \\
\hline Sarcococca conzattii & floden3834 & Calzada 19727 (TENN) \\
\hline Sarcococca conzattii & floden3835 & Calzada 19727 (TENN) \\
\hline Sarcococca conzattii & floden4073 & Skutch 553 (TX) \\
\hline
\end{tabular}


Sarcococca coriacea

Sarcococca coriacea

Sarcococca euphlebia

Sarcococca hookeriana

Sarcococca hookeriana

Sarcococca longipetiolata

Sarcococca longipetiolata

Sarcococca orientalis

Sarcococca philippinensis

Sarcococca ruscifolia

Sarcococca ruscifolia

Sarcococca ruscifolia

Sarcococca saligna

Sarcococca saligna

Sarcococca sp. Myanmar

Sarcococca wallichii

Sarcococca zeylanica

Sarcococca zeylanica

Styloceras brokawii

Styloceras brokawii

Styloceras brokawii

Styloceras columnare

Styloceras columnare

Styloceras connatum

Styloceras connatum

Styloceras kunthianum

Styloceras kunthianum

Styloceras kunthianum

Styloceras kunthianum

Styloceras laurifolium

Styloceras laurifolium

Styloceras laurifolium

Styloceras laurifolium

Styloceras laurifolium

$\begin{array}{ll}\text { B-648 } & \text { Nocolson 2712 (US-2571553) } \\ \text { B-650 } & \text { Bostick s.n. (US-29760003) } \\ \text { B-1801 } & \text { IBSC-0757158 } \\ \text { B-004 } & \text { No voucher, cultivated, photo in repository } \\ \text { B-646 } & \text { Bartholomew 1446 (US-3043590) } \\ \text { B-1804 } & \text { IBSC-0347445 } \\ \text { B-1812 } & \text { PE-00055950 } \\ \text { B-1811 } & \text { PE-01841407 } \\ \text { B-2001 } & \text { Benguel 4645 (M) } \\ \text { B-645 } & \text { Rock 11598 (US-1333178) } \\ \text { B-701 } & \text { Bartholomew 1912 (UC-1491879) } \\ \text { B-712a } & \text { Boufford 37718 (CAS-1103639) } \\ \text { B-644 } & \text { Nasir 397 (US-2395364) } \\ \text { floden3971 } & \text { Floden s.n. (TENN) } \\ \text { B-3005 } & \text { Hidetoshi 035324 (KYO) } \\ \text { B-643 } & \text { Bartholomew 688 (US-3068530) } \\ \text { B-642 } & \text { Huber 874 (US-2868259) } \\ \text { B-647 } & \text { Saldanha 10489 (US-2530653) } \\ \text { B-2101 } & \text { Nee 52239 (SPF-168130) } \\ \text { B-2151 } & \text { Nee 50191 (SP-350205) } \\ \text { B-606 } & \text { Nee 39225 (US-3250366) } \\ \text { B-1604 } & \text { Lewis 881062 (BRIT) } \\ \text { B-605 } & \text { Cardenas 52 (US-2325019) } \\ \text { B-401 } & \text { Macia 3993 (MO-5905935) } \\ \text { B-402 } & \text { Maldonado 2688 (MO-5734632) } \\ \text { B-2801 } & \text { Altemirano 157 (QCA-26086) } \\ \text { B-403 } & \text { van der Werff 10955 (MO-3657438) } \\ \text { B-404 } & \text { Rubio 2224 (MO-4293135) } \\ \text { B-818 } & \text { Bonpland 9208 (F-1012222) } \\ \text { B-1603 } & \text { Lewis 37398 (BRIT) } \\ \text { B-301 } & \text { No voucher, cultivated, photo in repository } \\ \text { B-400 } & \text { Veyton 1083 (MO-3012831) } \\ \text { B-603 } & \\ \text { B-815 } & \text { Young78 (US-2438721) } \\ & \end{array}$


Styloceras penninervium

Styloceras sp. Ecuador

Styloceras sp. Peru Oxapampa

Trochodendron aralioides

Trochodendron aralioides
B-427

B-604

B-2202

B-001

B-002
Smith 3206 (MO-3395324)

Clark 8910 (US-3500727)

Valenzuela 13978 (USM-252811)

No voucher, cultivated, photo in repository

No voucher, cultivated, photo in repository

Page 6 


$\begin{array}{ll}\text { Region } & \text { Sequenced fragment } \\ \text { Gabon } & \text { rbcl } \\ \text { Ivory Coast } & \text { rbcl, trnl } \\ \text { Gabon } & \text { rbcl } \\ \text { Cuba } & \text { rbcl, trnl } \\ \text { Jamaica } & \text { its, rbcl, trnl } \\ \text { Yunnan } & \text { its, rbcl, trnl } \\ \text { Bahamas } & \text { rbcl } \\ \text { Bahamas } & \text { trnl } \\ \text { Mallorca } & \text { its } \\ \text { Mexico } & \text { rbcl, trnl } \\ \text { Angola } & \text { its, rbcl, trnl } \\ \text { Cuba } & \text { rbcl } \\ \text { Guanxi } & \text { its, rbcl, trnl } \\ \text { Cuba } & \text { trnl } \\ \text { Cuba } & \text { rbcl, trnl } \\ \text { Cuba } & \text { its, rbcl, trnl } \\ \text { Cuba } & \text { rbcl } \\ \text { Madagascar } & \text { its, rbcl, trnl } \\ \text { Madagascar } & \text { its, rbcl, trnl } \\ \text { Guangdong } & \text { its, rbcl, trnl } \\ \text { Guangdong } & \text { its, rbcl, trnl } \\ \text { Madagascar } & \text { rbcl, trnl } \\ \text { Madagascar } & \text { its, rbcl, trnl } \\ \text { Suriname } & \text { rbcl, trnl } \\ \text { Thailand } & \text { rbcl } \\ \text { Thailand } & \text { rbcl } \\ \text { Thailand } & \text { rbcl, trnl } \\ \text { Tanzanam } & \text { rbcl } \\ \text { Tanzania } & \text { rbcl, trnl } \\ \text { Cuba } & \end{array}$




$\begin{array}{ll}\text { Cuba } & \text { rbcl, trnl } \\ \text { Cuba } & \text { rbcl, trnl } \\ \text { Hispaniola } & \text { its, rbcl, trnl } \\ \text { Cuba } & \text { rbcl, trnl } \\ \text { Cuba } & \text { trnl } \\ \text { Cuba } & \text { its, rbcl, trnl } \\ \text { Hainan } & \text { rbcl, trnl } \\ \text { Hong Kong } & \text { rbcl } \\ \text { Hunan } & \text { rbcl, trnl } \\ \text { Cuba } & \text { trnl } \\ \text { Ethiopia } & \text { rbcl } \\ \text { Madagascar } & \text { its, rbcl, trnl } \\ \text { Hubei } & \text { its, rbcl } \\ \text { Shaanxi } & \text { its, rbcl } \\ \text { Cuba } & \text { its, rbcl, trnl } \\ \text { Madagascar } & \text { its, rbcl, trnl } \\ \text { Madagascar } & \text { its, rbcl, trnl } \\ \text { Cuba } & \text { rbcl, trnl } \\ \text { Mexico } & \text { its, rbcl, trnl } \\ \text { Guanxi } & \text { its, rbcl } \\ \text { Guanxi } & \text { its, rbcl, trnl } \\ \text { Cuba } & \text { its, rbcl, trnl } \\ \text { Guanxi } & \text { rbcl } \\ \text { Okinawa } & \text { its, rbcl } \\ \text { Cape } & \text { its, rbcl, trnl } \\ \text { South Africa } & \text { rbcl, trnl } \\ \text { Madagascar } & \text { its, rbcl, trnl } \\ \text { Jamaica } & \text { rbcl, trnl } \\ \text { Madagascar } & \text { its, rbcl } \\ \text { Madagascar } & \text { its, rbcl, trnl } \\ \text { Madagascar } & \text { its, rbcl } \\ \text { Guba } & \\ \text { Mexico } & \text { itrnl } \\ \text { Cuadong } & \end{array}$




$\begin{array}{ll}\text { Mexico } & \text { its, rbcl, trnl } \\ \text { Korea } & \text { rbcl } \\ \text { Hubei } & \text { rbcl, trnl } \\ \text { Mexico } & \text { rbcl, trnl } \\ \text { Hong Kong } & \text { its, rbcl, trnl } \\ \text { Madagascar } & \text { its, rbcl, trnl } \\ \text { Madagascar } & \text { rbcl } \\ \text { Madagascar } & \text { its, rbcl, trnl } \\ \text { Madagascar } & \text { rbcl, trnl } \\ \text { Madagascar } & \text { its, rbcl, trnl } \\ \text { Cuba } & \text { rbcl } \\ \text { Hainan } & \text { rbcl, trnl } \\ \text { Hainan } & \text { its, rbcl, trnl } \\ \text { Cuba } & \text { rbcl } \\ \text { Malawi } & \text { its, rbcl } \\ \text { Cuba } & \text { trnl } \\ \text { Kenya } & \text { rbcl, trnl } \\ \text { Cuba } & \text { rbcl } \\ \text { Cuba } & \text { rbcl } \\ \text { Pakistan } & \text { its, trnl } \\ \text { Pakistan } & \text { its, trnl } \\ \text { Cuba } & \text { its, rbcl, trnl } \\ \text { Puerto Rico } & \text { trnl } \\ \text { Mexico } & \text { its, rbcl, trnl } \\ \text { Hainan } & \text { rbcl } \\ \text { Jamaica } & \text { rbcl } \\ \text { Jamaica } & \text { rbcl, trnl } \\ \text { Madagascar } & \text { its, rbcl } \\ \text { Cuba } & \text { rbcl, trnl } \\ \text { Cuba } & \\ \text { Cuba } & \text { itrnl } \\ \text { Cuba } & \text { itsand }\end{array}$




$\begin{array}{ll}\text { Sichuan } & \text { its, rbcl, trnl } \\ \text { USA } & \text { its } \\ \text { Azerbaijan } & \text { its, rbcl, trnl } \\ \text { Cuba } & \text { its, rbcl, trnl } \\ \text { Gansu } & \text { its, rbcl, trnl } \\ \text { Thailand } & \text { its, rbcl, trnl } \\ \text { China } & \text { rbcl } \\ \text { Sibuyan } & \text { its, rbcl } \\ \text { Hong Kong } & \text { its, rbcl, trnl } \\ \text { Martinique } & \text { its, rbcl, trnl } \\ \text { Cuba } & \text { rbcl } \\ \text { Cuba } & \text { its, rbcl, trnl } \\ \text { Puerto Rico } & \text { its, trnl } \\ \text { Puerto Rico } & \text { rbcl, trnl } \\ \text { Himachal Pradesh } & \text { its, rbcl, trnl } \\ \text { Madagascar } & \text { rbcl } \\ \text { Madagascar } & \text { its, rbcl, trnl } \\ \text { Madagascar } & \text { its, rbcl, trnl } \\ \text { Madagascar } & \text { rbcl } \\ \text { Madagascar } & \text { its } \\ \text { Sichuan } & \text { its, trnl } \\ \text { Yunnan } & \text { its } \\ \text { Sichuan } & \text { its, trnl } \\ \text { Tennessee } & \text { its, trnl } \\ \text { USA } & \text { its, rbcl } \\ \text { Vietnam } & \text { its, rbcl } \\ \text { Hainan } & \text { rbcl, trnl } \\ \text { Hainan } & \text { rbcl } \\ \text { Vietnam } & \text { its, rbcl, trnl } \\ \text { Cultivated } & \text { its, rbcl, trnl } \\ \text { Mexico } & \\ \text { Mexico } & \text { itrnl } \\ \text { Gexico } & \end{array}$




$\begin{array}{ll}\text { Nepal } & \text { its, rbcl } \\ \text { Cultivated } & \text { its, rbcl, trnl } \\ \text { Hainan } & \text { its, rbcl, trnl } \\ \text { USA } & \text { its, rbcl, trnl } \\ \text { Yunnan } & \text { its, rbcl, trnl } \\ \text { Guangdong } & \text { rbcl } \\ \text { Hunan } & \text { its, rbcl, trnl } \\ \text { Guanxi } & \text { its, rbcl, trnl } \\ \text { Luzon } & \text { rbcl, trnl } \\ \text { Yunnan } & \text { its, rbcl, trnl } \\ \text { Hubei } & \text { its, rbcl, trnl } \\ \text { Gansu } & \text { its, rbcl, trnl } \\ \text { Pakistan } & \text { its, rbcl, trnl } \\ \text { NA } & \text { its, trnl } \\ \text { Myanmar } & \text { its, rbcl } \\ \text { Yunnan } & \text { its, rbcl, trnl } \\ \text { Ceylon } & \text { its, rbcl } \\ \text { Tamil Nadu } & \text { its, rbcl, trnl } \\ \text { Bolivia } & \text { rbcl, trnl } \\ \text { Bolivia } & \text { rbcl } \\ \text { Bolivia } & \text { rbcl } \\ \text { Bolivia } & \text { rbcl, trnl } \\ \text { Bolivia } & \text { its, rbcl } \\ \text { Bolivia } & \text { its, rbcl } \\ \text { Bolivia } & \text { its } \\ \text { Ecuador } & \text { rbcl, trnl } \\ \text { Ecuador } & \text { its, rbcl } \\ \text { Ecuador } & \text { trnl } \\ \text { Ecuador } & \text { its, trnl } \\ \text { Bolivia } & \text { rbcl, trnl } \\ \text { Colombia } & \text { its } \\ \text { Peru } & \text { Peru }\end{array}$


bioRxiv preprint doi: https://doi.org/10.1101/2020.08.03.235267; this version posted August 7, 2020. The copyright holder has placed this preprint (which was not certified by peer review) in the Public Domain. It is no longer restricted by copyright. Anyone can legally share, reuse, remix, or adapt this material for any purpose without crediting the original authors.

\section{shipunov_floden_et_al_buxineae}

$\begin{array}{ll}\text { Peru } & \text { its, rbcl, trnl } \\ \text { Ecuador } & \text { rbcl } \\ \text { Peru } & \text { rbcl } \\ \text { USA } & \text { its } \\ \text { USA } & \text { its }\end{array}$

\section{Page 12}




\section{buxineae_dna_genbank_ids.txt}

$\begin{array}{lll}\text { Sequence ID } & \text { Fragment } & \text { GenBank ID } \\ \text { B-101 } & \text { its } & \text { MN537041 } \\ \text { B-722 } & \text { its } & \text { MN537042 } \\ \text { B-622 } & \text { its } & \text { MN537043 } \\ \text { B-202 } & \text { its } & \text { MN537044 } \\ \text { B-1819 } & \text { its } & \text { MN537045 } \\ \text { B-122 } & \text { its } & \text { MN537046 } \\ \text { B-426 } & \text { its } & \text { MN537047 } \\ \text { B-425 } & \text { its } & \text { MN537048 } \\ \text { B-1807 } & \text { its } & \text { MN537049 } \\ \text { B-1808 } & \text { its } & \text { MN537050 } \\ \text { B-100 } & \text { its } & \text { MN537051 } \\ \text { B-803 } & \text { its } & \text { MN537052 } \\ \text { B-409 } & \text { its } & \text { MN537053 } \\ \text { B-1815 } & \text { its } & \text { MN537054 } \\ \text { B-407 } & \text { its } & \text { MN537055 } \\ \text { B-713b } & \text { its } & \text { MN537056 } \\ \text { B-1810 } & \text { its } & \text { MN537057 } \\ \text { B-121 } & \text { its } & \text { MN537058 } \\ \text { B-619 } & \text { its } & \text { MN537059 } \\ \text { B-207 } & \text { its } & \text { MN537060 } \\ \text { B-406 } & \text { its } & \text { MN537061 } \\ \text { B-412 } & \text { its } & \text { MN537062 } \\ \text { B-1901 } & \text { its } & \text { MN537063 } \\ \text { B-712b } & \text { its } & \text { MN537064 } \\ \text { B-503 } & \text { its } & \text { MN537065 } \\ \text { B-112 } & \text { its } & \text { MN537066 } \\ \text { B-610 } & \text { its } & \text { MN537067 } \\ \text { B-706 } & \text { its } & \text { MN537068 } \\ \text { B-204 } & \text { its } & \text { MN537069 } \\ \text { B-617 } & \text { its } & \text { MN537070 } \\ \text { B-111 } & \text { its } & \text { MN537071 } \\ \text { B-636 }-414 ~ & \text { MN537072 } \\ \text { B-104 } & \text { its537074 } \\ \text { B } & & \end{array}$




\section{buxineae_dna_genbank_ids.txt}

\begin{tabular}{|c|c|c|}
\hline B-614 & its & MN537076 \\
\hline B-721 & its & MN537077 \\
\hline B-003 & its & MN537078 \\
\hline B-302 & its & MN537079 \\
\hline B-627 & its & MN537080 \\
\hline B-720 & its & MN537081 \\
\hline B-500 & its & MN537082 \\
\hline B-506 & its & MN537083 \\
\hline B-1903 & its & MN537084 \\
\hline B-626 & its & MN537085 \\
\hline B-126 & its & MN537086 \\
\hline B-615 & its & MN537087 \\
\hline B-601 & its & MN537088 \\
\hline B-415 & its & MN537089 \\
\hline B-423 & its & MN537090 \\
\hline B-639 & its & MN537091 \\
\hline B-640 & its & MN537092 \\
\hline B-005 & its & MN537093 \\
\hline B-303 & its & MN537094 \\
\hline floden3847 & its & MN537095 \\
\hline B-713a & its & MN537096 \\
\hline floden3835 & its & MN537097 \\
\hline floden4073 & its & MN537098 \\
\hline B-648 & its & MN537099 \\
\hline B-650 & its & MN537100 \\
\hline B-004 & its & MN537101 \\
\hline B-1812 & its & MN537102 \\
\hline B-1811 & its & MN537103 \\
\hline B-645 & its & MN537104 \\
\hline B-644 & its & MN537105 \\
\hline floden3971 & its & MN537106 \\
\hline B-1801 & its & MN537107 \\
\hline B-3005 & its & MN537108 \\
\hline B-643 & its & MN537109 \\
\hline B-605 & its & MN537110 \\
\hline B-401 & its & MN537111 \\
\hline
\end{tabular}

\section{Page 2}




\section{buxineae_dna_genbank_ids.txt}

\begin{tabular}{|c|c|c|}
\hline B-403 & its & MN537112 \\
\hline B-818 & its & MN537113 \\
\hline B-301 & its & MN537114 \\
\hline B-427 & its & MN537115 \\
\hline B-001 & its & MN537116 \\
\hline B-1816 & its & MN537117 \\
\hline B-408 & its & MN537118 \\
\hline B-1814 & its & MN537119 \\
\hline B-413 & its & MN537120 \\
\hline B-723 & its & MN537121 \\
\hline B-411 & its & MN537122 \\
\hline B-705 & its & MN537123 \\
\hline B-703 & its & MN537124 \\
\hline B-646 & its & MN537125 \\
\hline B-701 & its & MN537126 \\
\hline B-402 & its & MN537127 \\
\hline B-400 & its & MN537128 \\
\hline B-002 & its & MN537129 \\
\hline B-611 & its & MN537130 \\
\hline B-714 & its & MN537131 \\
\hline B-712a & its & MN537132 \\
\hline B-603 & its & MN537133 \\
\hline B-004 & $\mathrm{rbcl}$ & MN579948 \\
\hline B-005 & $\mathrm{rbcl}$ & MN579949 \\
\hline B-100 & $\mathrm{rbcl}$ & MN579950 \\
\hline B-101 & $\mathrm{rbcl}$ & MN579951 \\
\hline B-104 & $\mathrm{rbcl}$ & MN579952 \\
\hline B-105 & $\mathrm{rbcl}$ & MN579953 \\
\hline B-106 & $\mathrm{rbcl}$ & MN579954 \\
\hline B-107 & $\mathrm{rbcl}$ & MN579955 \\
\hline B-109 & rbcl & MN579956 \\
\hline B-111 & $\mathrm{rbcl}$ & MN579957 \\
\hline B-112 & $\mathrm{rbcl}$ & MN579958 \\
\hline B-113 & $\mathrm{rbcl}$ & MN579959 \\
\hline B-114 & $\mathrm{rbcl}$ & MN579960 \\
\hline B-115 & $\mathrm{rbcl}$ & MN579961 \\
\hline
\end{tabular}




\section{buxineae_dna_genbank_ids.txt}

\begin{tabular}{|c|c|c|}
\hline B-116 & $\mathrm{rbcl}$ & MN579962 \\
\hline B-117 & $\mathrm{rbcl}$ & MN579963 \\
\hline B-118 & rbcl & MN579964 \\
\hline B-121 & $\mathrm{rbcl}$ & MN579965 \\
\hline B-122 & rbcl & MN579966 \\
\hline B-123 & rbcl & MN579967 \\
\hline B-125 & $\mathrm{rbcl}$ & MN579968 \\
\hline B-126 & $\mathrm{rbcl}$ & MN579969 \\
\hline B-1601 & $\mathrm{rbcl}$ & MN579970 \\
\hline B-1602 & $\mathrm{rbcl}$ & MN579971 \\
\hline B-1603 & $\mathrm{rbcl}$ & MN579972 \\
\hline B-1604 & $\mathrm{rbcl}$ & MN579973 \\
\hline B-1801 & $\mathrm{rbcl}$ & MN579974 \\
\hline B-1804 & $\mathrm{rbcl}$ & MN579975 \\
\hline B-1805 & $\mathrm{rbcl}$ & MN579976 \\
\hline B-1807 & $\mathrm{rbcl}$ & MN579977 \\
\hline B-1808 & $\mathrm{rbcl}$ & MN579978 \\
\hline B-1809 & $\mathrm{rbcl}$ & MN579979 \\
\hline B-1810 & $\mathrm{rbcl}$ & MN579980 \\
\hline B-1811 & $\mathrm{rbcl}$ & MN579981 \\
\hline B-1812 & $\mathrm{rbcl}$ & MN579982 \\
\hline B-1814 & $\mathrm{rbcl}$ & MN579983 \\
\hline B-1815 & $\mathrm{rbcl}$ & MN579984 \\
\hline B-1816 & $\mathrm{rbcl}$ & MN579985 \\
\hline B-1817 & $\mathrm{rbcl}$ & MN579986 \\
\hline B-1818 & rbcl & MN579987 \\
\hline B-1819 & $\mathrm{rbcl}$ & MN579988 \\
\hline B-1901 & $\mathrm{rbcl}$ & MN579989 \\
\hline B-1902 & rbcl & MN579990 \\
\hline B-1903 & rbcl & MN579991 \\
\hline B-200 & $\mathrm{rbcl}$ & MN579992 \\
\hline B-2001 & $\mathrm{rbcl}$ & MN579993 \\
\hline B-201 & $\mathrm{rbcl}$ & MN579994 \\
\hline B-202 & $\mathrm{rbcl}$ & MN579995 \\
\hline B-204 & $\mathrm{rbcl}$ & MN579996 \\
\hline B-205 & rbcl & MN579997 \\
\hline
\end{tabular}




\section{buxineae_dna_genbank_ids.txt}

\begin{tabular}{|c|c|c|}
\hline B-206 & $\mathrm{rbcl}$ & MN579998 \\
\hline B-207 & $\mathrm{rbcl}$ & MN579999 \\
\hline B-2101 & $\mathrm{rbcl}$ & MN580000 \\
\hline B-2151 & $\mathrm{rbcl}$ & MN580001 \\
\hline B-2202 & $\mathrm{rbcl}$ & MN580002 \\
\hline B-2801 & $\mathrm{rbcl}$ & MN580003 \\
\hline B-3005 & $\mathrm{rbcl}$ & MN580004 \\
\hline B-302 & $\mathrm{rbcl}$ & MN580005 \\
\hline B-303 & $\mathrm{rbcl}$ & MN580006 \\
\hline B-401 & $\mathrm{rbcl}$ & MN580007 \\
\hline B-403 & $\mathrm{rbcl}$ & MN580008 \\
\hline B-406 & $\mathrm{rbcl}$ & MN580009 \\
\hline B-407 & $\mathrm{rbcl}$ & MN580010 \\
\hline B-408 & $\mathrm{rbcl}$ & MN580011 \\
\hline B-409 & $\mathrm{rbcl}$ & MN580012 \\
\hline B-410 & $\mathrm{rbcl}$ & MN580013 \\
\hline B-411 & $\mathrm{rbcl}$ & MN580014 \\
\hline B-412 & $\mathrm{rbcl}$ & MN580015 \\
\hline B-413 & $\mathrm{rbcl}$ & MN580016 \\
\hline B-414 & $\mathrm{rbcl}$ & MN580017 \\
\hline B-415 & $\mathrm{rbcl}$ & MN580018 \\
\hline B-417 & $\mathrm{rbcl}$ & MN580019 \\
\hline B-418 & $\mathrm{rbcl}$ & MN580020 \\
\hline B-420 & $\mathrm{rbcl}$ & MN580021 \\
\hline B-421 & $\mathrm{rbcl}$ & MN580022 \\
\hline B-422 & $\mathrm{rbcl}$ & MN580023 \\
\hline B-425 & $\mathrm{rbcl}$ & MN580024 \\
\hline B-426 & $\mathrm{rbcl}$ & MN580025 \\
\hline B-427 & $\mathrm{rbcl}$ & MN580026 \\
\hline B-500 & $\mathrm{rbcl}$ & MN580027 \\
\hline B-503 & $\mathrm{rbcl}$ & MN580028 \\
\hline B-505 & $\mathrm{rbcl}$ & MN580029 \\
\hline B-506 & $\mathrm{rbcl}$ & MN580030 \\
\hline B-510 & $\mathrm{rbcl}$ & MN580031 \\
\hline B-601 & $\mathrm{rbcl}$ & MN580032 \\
\hline B-602 & $\mathrm{rbcl}$ & MN580033 \\
\hline
\end{tabular}




\section{buxineae_dna_genbank_ids.txt}

\begin{tabular}{lll} 
B-603 & $\mathrm{rbcl}$ & MN580034 \\
B-604 & $\mathrm{rbcl}$ & MN580035 \\
B-605 & $\mathrm{rbcl}$ & MN580036 \\
B-606 & $\mathrm{rbcl}$ & MN580037 \\
B-610 & $\mathrm{rbcl}$ & MN580038 \\
B-611 & $\mathrm{rbcl}$ & MN580039 \\
B-612 & $\mathrm{rbcl}$ & MN580040 \\
B-614 & $\mathrm{rbcl}$ & MN580041 \\
B-615 & $\mathrm{rbcl}$ & MN580042 \\
B-616 & $\mathrm{rbcl}$ & MN580043 \\
B-618 & $\mathrm{rbcl}$ & MN580044 \\
B-619 & $\mathrm{rbcl}$ & MN580045 \\
B-620 & $\mathrm{rbcl}$ & MN580046 \\
B-621 & $\mathrm{rbcl}$ & MN580047 \\
B-623 & $\mathrm{rbcl}$ & MN580048 \\
B-626 & $\mathrm{rbcl}$ & MN580049 \\
B-627 & $\mathrm{rbcl}$ & MN580050 \\
B-629 & $\mathrm{rbcl}$ & MN580051 \\
B-630 & $\mathrm{rbcl}$ & MN580052 \\
B-631 & $\mathrm{rbcl}$ & MN580053 \\
B-634 & $\mathrm{rbcl}$ & MN580054 \\
B-636 & $\mathrm{rbcl}$ & MN580055 \\
B-642 & $\mathrm{rbcl}$ & MN580056 \\
B-643 & $\mathrm{rbcl}$ & MN580057 \\
B-644 & $\mathrm{rbcl}$ & MN580058 \\
B-645 & $\mathrm{rbcl}$ & MN580059 \\
B-646 & $\mathrm{rbcl}$ & MN580060 \\
B-647 & $\mathrm{rbcl}$ & MN580061 \\
B-648 & $\mathrm{rbcl}$ & MN580062 \\
B-649 & $\mathrm{rbcl}$ & MN580063 \\
B-650 & $\mathrm{rbcl}$ & MN580064 \\
B-651 & $\mathrm{rbcl}$ & MN580065 \\
B-701 & MN580066 \\
\hline
\end{tabular}




\section{buxineae_dna_genbank_ids.txt}

\begin{tabular}{|c|c|c|}
\hline B-710 & $\mathrm{rbcl}$ & MN580070 \\
\hline B-711 & $\mathrm{rbcl}$ & MN580071 \\
\hline B-712a & rbcl & MN580072 \\
\hline B-712b & $\mathrm{rbcl}$ & MN580073 \\
\hline B-713a & rbcl & MN580074 \\
\hline B-713b & rbcl & MN580075 \\
\hline B-716 & $\mathrm{rbcl}$ & MN580076 \\
\hline B-717 & $\mathrm{rbcl}$ & MN580077 \\
\hline B-718 & $\mathrm{rbcl}$ & MN580078 \\
\hline B-720 & $\mathrm{rbcl}$ & MN580079 \\
\hline B-721 & $\mathrm{rbcl}$ & MN580080 \\
\hline B-722 & $\mathrm{rbcl}$ & MN580081 \\
\hline B-723 & $\mathrm{rbcl}$ & MN580082 \\
\hline B-724 & $\mathrm{rbcl}$ & MN580083 \\
\hline B-802 & $\mathrm{rbcl}$ & MN580084 \\
\hline B-803 & $\mathrm{rbcl}$ & MN580085 \\
\hline B-807 & $\mathrm{rbcl}$ & MN580086 \\
\hline B-808 & $\mathrm{rbcl}$ & MN580087 \\
\hline B-809 & $\mathrm{rbcl}$ & MN580088 \\
\hline B-810 & $\mathrm{rbcl}$ & MN580089 \\
\hline B-811 & $\mathrm{rbcl}$ & MN580090 \\
\hline B-817 & $\mathrm{rbcl}$ & MN580091 \\
\hline floden3834 & $\mathrm{rbcl}$ & MN580092 \\
\hline floden3847 & $\mathrm{rbcl}$ & MN580093 \\
\hline B-420 & $\operatorname{trnl}$ & MN549158 \\
\hline B-118 & trnl & MN549159 \\
\hline B-101 & trnl & MN549160 \\
\hline B-722 & $\operatorname{trnl}$ & MN549161 \\
\hline B-635 & trnl & MN549162 \\
\hline B-716 & $\operatorname{trnl}$ & MN549163 \\
\hline B-202 & $\operatorname{trnl}$ & MN549164 \\
\hline B-1819 & trnl & MN549165 \\
\hline B-103 & $\operatorname{trnl}$ & MN549166 \\
\hline B-122 & trnl & MN549167 \\
\hline B-426 & trnl & MN549168 \\
\hline B-425 & trnl & MN549169 \\
\hline
\end{tabular}




\section{buxineae_dna_genbank_ids.txt}

$\begin{array}{lll}\text { B-1807 } & \text { trnl } & \text { MN549170 } \\ \text { B-1808 } & \text { trnl } & \text { MN549171 } \\ \text { B-205 } & \text { trnl } & \text { MN549172 } \\ \text { B-623 } & \text { trnl } & \text { MN549173 } \\ \text { B-621 } & \text { trnl } & \text { MN549174 } \\ \text { B-200 } & \text { trnl } & \text { MN549175 } \\ \text { B-422 } & \text { trnl } & \text { MN549176 } \\ \text { B-100 } & \text { trnl } & \text { MN549177 } \\ \text { B-114 } & \text { trnl } & \text { MN549178 } \\ \text { B-107 } & \text { trnl } & \text { MN549179 } \\ \text { B-106 } & \text { trnl } & \text { MN549180 } \\ \text { B-631 } & \text { trnl } & \text { MN549181 } \\ \text { B-632 } & \text { trnl } & \text { MN549182 } \\ \text { B-717 } & \text { trnl } & \text { MN549183 } \\ \text { B-718 } & \text { trnl } & \text { MN549184 } \\ \text { B-119 } & \text { trnl } & \text { MN549185 } \\ \text { B-409 } & \text { trnl } & \text { MN549186 } \\ \text { B-710 } & \text { trnl } & \text { MN549187 } \\ \text { B-407 } & \text { trnl } & \text { MN549188 } \\ \text { B-123 } & \text { trnl } & \text { MN549189 } \\ \text { B-713b } & \text { trnl } & \text { MN549190 } \\ \text { B-1814 } & \text { trnl } & \text { MN549191 } \\ \text { B-121 } & \text { trnl } & \text { MN549192 } \\ \text { B-207 } & \text { trnl } & \text { MN549193 } \\ \text { B-406 } & \text { trnl } & \text { MN549194 } \\ \text { B-630 } & \text { trnl } & \text { MN549195 } \\ \text { B-413 } & \text { trnl } & \text { MN549196 } \\ \text { B-629 } & \text { trnl } & \text { MN549197 } \\ \text { B-1901 } & \text { trnl } & \text { MN549198 } \\ \text { B-712b } & \text { trnl } & \text { MN549199 } \\ \text { B-704 } & \text { trnl } & \text { MN549200 } \\ \text { B-724 } & \text { trnl } & \text { MN549201 } \\ \text { B-112 } & \text { trnl } & \text { MN549202 } \\ \text { Brnl } & \text { MN549203 } \\ \text { Brnl } & \text { MN549204 } \\ \text { Brnl } & \text { MN549205 }\end{array}$




\section{buxineae_dna_genbank_ids.txt}

$\begin{array}{lll}\text { B-706 } & \text { trnl } & \text { MN549206 } \\ \text { B-110 } & \text { trnl } & \text { MN549207 } \\ \text { B-810 } & \text { trnl } & \text { MN549208 } \\ \text { B-617 } & \text { trnl } & \text { MN549209 } \\ \text { B-111 } & \text { trnl } & \text { MN549210 } \\ \text { B-816 } & \text { trnl } & \text { MN549211 } \\ \text { B-636 } & \text { trnl } & \text { MN549212 } \\ \text { B-802 } & \text { trnl } & \text { MN549213 } \\ \text { B-105 } & \text { trnl } & \text { MN549214 } \\ \text { B-104 } & \text { trnl } & \text { MN549215 } \\ \text { B-117 } & \text { trnl } & \text { MN549216 } \\ \text { B-614 } & \text { trnl } & \text { MN549217 } \\ \text { B-115 } & \text { trnl } & \text { MN549218 } \\ \text { B-721 } & \text { trnl } & \text { MN549219 } \\ \text { B-302 } & \text { trnl } & \text { MN549220 } \\ \text { B-627 } & \text { trnl } & \text { MN549221 } \\ \text { B-720 } & \text { trnl } & \text { MN549222 } \\ \text { B-500 } & \text { trnl } & \text { MN549223 } \\ \text { B-1903 } & \text { trnl } & \text { MN549224 } \\ \text { B-626 } & \text { trnl } & \text { MN549225 } \\ \text { B-126 } & \text { trnl } & \text { MN549226 } \\ \text { B-625 } & \text { trnl } & \text { MN549227 } \\ \text { B-615 } & \text { trnl } & \text { MN549228 } \\ \text { B-601 } & \text { trnl } & \text { MN549229 } \\ \text { B-415 } & \text { trnl } & \text { MN549230 } \\ \text { B-639 } & \text { trnl } & \text { MN549231 } \\ \text { B-640 } & \text { trnl } & \text { MN549232 } \\ \text { B-649 } & \text { trnl } & \text { MN549233 } \\ \text { Bloden3847 } & \text { trnl } & \text { MN549234 } \\ \text { B-713a } & \text { trnl } & \text { MN549235 } \\ \text { B-651 } & \text { trnl } & \text { MN549236 } \\ \text { B-650 } & \text { trnl } & \text { MN549237 } \\ \text { B-1812 } & \text { trnl } & \text { MN549238 } \\ \text { trnl } & \text { MN549239 } \\ \text { Brnl } & \text { MN549240 } \\ \text { Brnl } & \text { MN549241 }\end{array}$




\section{buxineae_dna_genbank_ids.txt}

$\begin{array}{lll}\text { B-645 } & \text { trnl } & \text { MN549242 } \\ \text { B-644 } & \text { trnl } & \text { MN549243 } \\ \text { floden3971 } & \text { trnl } & \text { MN549244 } \\ \text { B-1801 } & \text { trnl } & \text { MN549245 } \\ \text { B-643 } & \text { trnl } & \text { MN549246 } \\ \text { B-647 } & \text { trnl } & \text { MN549247 } \\ \text { B-2101 } & \text { trnl } & \text { MN549248 } \\ \text { B-1604 } & \text { trnl } & \text { MN549249 } \\ \text { B-2801 } & \text { trnl } & \text { MN549250 } \\ \text { B-404 } & \text { trnl } & \text { MN549251 } \\ \text { B-301 } & \text { trnl } & \text { MN549252 } \\ \text { B-427 } & \text { trnl } & \text { MN549253 } \\ \text { B-125 } & \text { trnl } & \text { MN549254 } \\ \text { B-206 } & \text { trnl } & \text { MN549255 } \\ \text { B-1602 } & \text { trnl } & \text { MN549256 } \\ \text { B-711 } & \text { trnl } & \text { MN549257 } \\ \text { B-803 } & \text { trnl } & \text { MN549258 } \\ \text { B-408 } & \text { trnl } & \text { MN549259 } \\ \text { B-612 } & \text { trnl } & \text { MN549260 } \\ \text { B-723 } & \text { trnl } & \text { MN549261 } \\ \text { B-411 } & \text { trnl } & \text { MN549262 } \\ \text { B-610 } & \text { trnl } & \text { MN549263 } \\ \text { B-705 } & \text { trnl } & \text { MN549264 } \\ \text { B-502 } & \text { trnl } & \text { MN549265 } \\ \text { B-807 } & \text { trnl } & \text { MN549266 } \\ \text { B-714 } & \text { trnl } & \text { MN549267 } \\ \text { floden3834 } & \text { trnl } & \text { MN549268 } \\ \text { B-646 } & \text { trnl } & \text { MN549269 } \\ \text { B-701 } & \text { trnl } & \text { MN549270 } \\ \text { B-818 } & \text { trnl } & \text { MN549271 } \\ \text { B-603 } & \text { trnl } & \text { MN549272 } \\ \text { floden3835 } & \text { trnl } & \text { MN549273 } \\ \text { B-812a } & \text { trnl } & \text { MN549274 } \\ \text { fleden4073 } & \text { trnl } & \text { MN549275 } \\ \text { Bnl } & \text { trnl } & \text { MN549277 }\end{array}$


04_buxaceae_used_genbank_ids.tx

\begin{tabular}{|c|c|c|}
\hline GenBank ID & Species & Fragme \\
\hline JF978888 & Tetracentron sinense & its \\
\hline AF245416 & Sarcococca confertiflora & its \\
\hline slx077 & Haptanthus hazlettii & its \\
\hline AF245425 & Buxus natalensis & its \\
\hline AF245412 & Buxus microphylla & its \\
\hline AF245415 & Buxus hildebrandtii & its \\
\hline AF245409 & Buxus henryi & its \\
\hline AF245410 & Buxus harlandii & its \\
\hline AF245433 & Buxus citrifolia & its \\
\hline AF245434 & Buxus acutata & its \\
\hline GQ998807 & Trochodendron aralioides & matk \\
\hline AM396504 & Tetracentron sinense & matk \\
\hline LN877480 & Styloceras laurifolium & matk \\
\hline LN877483 & Sarcococca saligna & matk \\
\hline LN877488 & Sarcococca hookeriana & matk \\
\hline LN877481 & Sarcococca conzattii & matk \\
\hline LN877482 & Sarcococca confusa & matk \\
\hline AF542581 & Pachysandra terminalis & matk \\
\hline GU266592 & Pachysandra procumbens & matk \\
\hline KX526614 & Pachysandra axillaris & matk \\
\hline LN877495 & Haptanthus hazlettii & matk \\
\hline DQ401354 & Didymeles perrieri & matk \\
\hline LN877440 & Buxus yunquensis & matk \\
\hline LN877502 & Buxus wrightii & matk \\
\hline LN877443 & Buxus vahlii & matk \\
\hline LN877458 & Buxus triptera & matk \\
\hline KP088983 & Buxus sinica & matk \\
\hline LN877400 & Buxus shaferi & matk \\
\hline LN877419 & Buxus serpentinicola & matk \\
\hline LN877449 & Buxus sempervirens & matk \\
\hline LN877418 & Buxus sclerophylla & matk \\
\hline LN877399 & Buxus rotundifolia & matk \\
\hline LN877471 & Buxus rheedioides & matk \\
\hline LN877431 & Buxus revoluta & matk \\
\hline LN877408 & Buxus retusa & matk \\
\hline LN877496 & Buxus pubescens & matk \\
\hline LN877417 & Buxus pseudaneura & matk \\
\hline LN877484 & Buxus portoricensis & matk \\
\hline LN877416 & Buxus pilosula & matk \\
\hline MG946997 & Buxus papillosa & matk \\
\hline LN877415 & Buxus olivacea & matk \\
\hline HG004438 & Buxus nipensis & matk \\
\hline LN877461 & Buxus natalensis & matk \\
\hline
\end{tabular}


04_buxaceae_used_genbank_ids.tx

$\begin{array}{lll}\text { AF186395 } & \text { Buxus muelleriana } & \text { matk } \\ \text { LN877494 } & \text { Buxus moratii } & \text { matk } \\ \text { LN877412 } & \text { Buxus moctezumae } & \text { matk } \\ \text { LN877411 } & \text { Buxus moana } & \text { matk } \\ \text { LN877447 } & \text { Buxus microphylla } & \text { matk } \\ \text { LN877442 } & \text { Buxus mexicana } & \text { matk } \\ \text { LN877410 } & \text { Buxus marginalis } & \text { matk } \\ \text { LN877498 } & \text { Buxus madagascarica } & \text { matk } \\ \text { LN877460 } & \text { Buxus macowanii } & \text { matk } \\ \text { LN877413 } & \text { Buxus leivae } & \text { matk } \\ \text { HG004433 } & \text { Buxus koehleri } & \text { matk } \\ \text { LN877409 } & \text { Buxus jaucoensis } & \text { matk } \\ \text { LN877441 } & \text { Buxus imbricata } & \text { matk } \\ \text { LN877462 } & \text { Buxus hildebrandtii } & \text { matk } \\ \text { AF186398 } & \text { Buxus harlandii } & \text { matk } \\ \text { LN877426 } & \text { Buxus gonoclada } & \text { matk } \\ \text { LN877439 } & \text { Buxus glomerata } & \text { matk } \\ \text { LN877407 } & \text { Buxus foliosa } & \text { matk } \\ \text { LN877406 } & \text { Buxus excisa } & \text { matk } \\ \text { LN877405 } & \text { Buxus ekmanii } & \text { matk } \\ \text { HG004434 } & \text { Buxus cristalensis } & \text { matk } \\ \text { LN877398 } & \text { Buxus crassifolia } & \text { matk } \\ \text { LN877497 } & \text { Buxus citrifolia } & \text { matk } \\ \text { LN877486 } & \text { Buxus brevipes } & \text { matk } \\ \text { LN877453 } & \text { Buxus braimbridgeorum } & \text { matk } \\ \text { LN877404 } & \text { Buxus bissei } & \text { matk } \\ \text { LN877459 } & \text { Buxus benguellensis } & \text { matk } \\ \text { LN877403 } & \text { Buxus bartlettii } & \text { matk } \\ \text { LN877446 } & \text { Buxus balearica } & \text { matk } \\ \text { LN877421 } & \text { Buxus bahamensis } & \text { matk } \\ \text { LN877444 } & \text { Buxus arborea } & \text { matk } \\ \text { LN877397 } & \text { Buxus aneura } & \text { matk } \\ \text { LN877402 } & \text { Buxus acunae } & \text { matk } \\ \text { AY590833 } & \text { Trochodendron aralioides } & \text { petd } \\ \text { AM396539 } & \text { Tetracentron sinense } & \text { petd } \\ \text { LN877590 } & \text { Styloceras laurifolium } & \text { petd } \\ \text { LN877593 } & \text { Sarcococca saligna } & \text { petd } \\ \text { LN877598 } & \text { Sarcococca hookeriana } & \text { petd } \\ \text { LN877591 } & \text { Sarcococca conzattii } & \text { petd } \\ \text { LN877592 } & \text { Sarcococca confusa } & \text { petd } \\ \text { AM396541 } & \text { Pachysandra terminalis } & \text { petd } \\ \text { LN877605 } & \text { Haptanthus hazlettii } & \text { petd } \\ \text { LN877548 } & \text { Didymeles integrifolia } & \text { petd } \\ & \text { Buxus yunquensis } & \text { petd }\end{array}$


04_buxaceae_used_genbank_ids.tx

$\begin{array}{lll}\text { LN877612 } & \text { Buxus wrightii } & \text { petd } \\ \text { LN877595 } & \text { Buxus vahlii } & \text { petd } \\ \text { LN877567 } & \text { Buxus triptera } & \text { petd } \\ \text { LN877544 } & \text { Buxus shaferi } & \text { petd } \\ \text { LN877527 } & \text { Buxus serpentinicola } & \text { petd } \\ \text { AY590832 } & \text { Buxus sempervirens } & \text { petd } \\ \text { LN877526 } & \text { Buxus sclerophylla } & \text { petd } \\ \text { LN877579 } & \text { Buxus rotundifolia } & \text { petd } \\ \text { LN877537 } & \text { Buxus rheedioides } & \text { petd } \\ \text { LN877541 } & \text { Buxus revoluta } & \text { petd } \\ \text { LN877578 } & \text { Buxus retusa } & \text { petd } \\ \text { LN877606 } & \text { Buxus pubescens } & \text { petd } \\ \text { LN877524 } & \text { Buxus pseudaneura } & \text { petd } \\ \text { LN877594 } & \text { Buxus portoricensis } & \text { petd } \\ \text { LN877575 } & \text { Buxus pilosula } & \text { petd } \\ \text { LN877577 } & \text { Buxus olivacea } & \text { petd } \\ \text { LN877580 } & \text { Buxus nipensis } & \text { petd } \\ \text { LN877570 } & \text { Buxus natalensis } & \text { petd } \\ \text { LN877604 } & \text { Buxus moratii } & \text { petd } \\ \text { LN877519 } & \text { Buxus moctezumae } & \text { petd } \\ \text { LN877518 } & \text { Buxus moana } & \text { petd } \\ \text { LN877557 } & \text { Buxus microphylla } & \text { petd } \\ \text { LN877551 } & \text { Buxus mexicana } & \text { petd } \\ \text { LN877517 } & \text { Buxus marginalis } & \text { petd } \\ \text { LN877608 } & \text { Buxus madagascarica } & \text { petd } \\ \text { LN877569 } & \text { Buxus macowanii } & \text { petd } \\ \text { LN877520 } & \text { Buxus leivae } & \text { petd } \\ \text { LN877550 } & \text { Buxus koehleri } & \text { petd } \\ \text { LN877516 } & \text { Buxus jaucoensis } & \text { petd } \\ \text { LN877549 } & \text { Buxus imbricata } & \text { petd } \\ \text { LN877571 } & \text { Buxus hildebrandtii } & \text { petd } \\ \text { LN877546 } & \text { Buxus gonoclada } & \text { petd } \\ \text { LN877534 } & \text { Buxus glomerata } & \text { petd } \\ \text { LN877514 } & \text { Buxus foliosa } & \text { petd } \\ \text { LN877513 } & \text { Buxus excisa } & \text { petd } \\ \text { LN877565 } & \text { Buxus ekmanii } & \text { petd } \\ \text { LN877525 } & \text { Buxus cristalensis } & \text { petd } \\ \text { LN877505 } & \text { Buxus crassifolia } & \text { petd } \\ \text { LN877607 } & \text { Buxus citrifolia } & \text { petd } \\ \text { LN877596 } & \text { Buxus brevipes } & \text { petd } \\ \text { LN877562 } & \text { Buxus braimbridgeorum } & \text { petd } \\ \text { LN877511 } & \text { Buxus bissei } & \text { petd } \\ \text { LN877568 } & \text { Buxus benguellensis } & \text { petd } \\ \text { LN877510 } & \text { Buxus bartlettii } & \text { petd }\end{array}$




\section{4_buxaceae_used_genbank_ids.tx}

$\begin{array}{lll}\text { LN877555 } & \text { Buxus balearica } & \text { petd } \\ \text { LN877529 } & \text { Buxus bahamensis } & \text { petd } \\ \text { LN877553 } & \text { Buxus arborea } & \text { petd } \\ \text { LN877504 } & \text { Buxus aneura } & \text { petd } \\ \text { LN877509 } & \text { Buxus acunae } & \text { petd } \\ \text { LN877508 } & \text { Buxus acuminata } & \text { petd } \\ \text { GQ998840 } & \text { Trochodendron aralioides } & \text { rbcl } \\ \text { L12668 } & \text { Tetracentron sinense } & \text { rbcl } \\ \text { AF061993 } & \text { Pachysandra procumbens } & \text { rbcl } \\ \text { AF203485 } & \text { Pachysandra axillaris } & \text { rbcl } \\ \text { HQ634681 } & \text { Haptanthus hazlettii } & \text { rbcl } \\ \text { DQ182333 } & \text { Buxus sempervirens } & \text { rbcl } \\ \text { KJ082152 } & \text { Buxus portoricensis } & \text { rbcl } \\ \text { MG946885 } & \text { Buxus papillosa } & \text { rbcl } \\ \text { MG946906 } & \text { Buxus natalensis } & \text { rbcl } \\ \text { HE963365 } & \text { Buxus balearica } & \text { rbcl } \\ \text { AY145360 } & \text { Trochodendron aralioides } & \text { trnl } \\ \text { AM397165 } & \text { Tetracentron sinense } & \text { trnl } \\ \text { AM397167 } & \text { Pachysandra terminalis } & \text { trnl } \\ \text { slx077 } & \text { Haptanthus hazlettii } & \text { trnl } \\ \text { AM397166 } & \text { Didymeles integrifolia } & \text { trnl } \\ \text { LN877657 } & \text { Buxus yunquensis } & \text { trnl } \\ \text { LN877719 } & \text { Buxus wrightii } & \text { trnl } \\ \text { LN877675 } & \text { Buxus triptera } & \text { trnl } \\ \text { LN877636 } & \text { Buxus serpentinicola } & \text { trnl } \\ \text { AY145357 } & \text { Buxus sempervirens } & \text { trnl } \\ \text { LN877635 } & \text { Buxus sclerophylla } & \text { trnl } \\ \text { LN877634 } & \text { Buxus pseudaneura } & \text { trnl } \\ \text { LN877632 } & \text { Buxus olivacea } & \text { trnl } \\ \text { HG004431 } & \text { Buxus nipensis } & \text { trnl } \\ \text { LN877678 } & \text { Buxus natalensis } & \text { trnl } \\ \text { LN877628 } & \text { Buxus moana } & \text { trnl } \\ \text { AB817516 } & \text { Buxus liukiuensis } & \text { trnl } \\ \text { LN877630 } & \text { Buxus leivae } & \text { trnl } \\ \text { HG004428 } & \text { Buxus koehleri } & \text { trnl } \\ \text { LN877626 } & \text { Buxus jaucoensis } & \text { trnl } \\ \text { LN877679 } & \text { Buxus hildebrandtii } & \text { trnl } \\ \text { AF200930 } & \text { Buxus harlandii } & \text { trnl } \\ \text { LN877622 } & \text { Buxus ekmanii } & \text { trnl } \\ \text { HG004429 } & \text { Buxus cristalensis } & \text { trnl } \\ \text { LN877621 } & \text { Buxus bissei } & \text { trnl } \\ \text { LN877663 } & \text { Buxus balearica } & \text { trnl } \\ \text { LN877619 } & \text { Buxus acunae } & \text { trnl } \\ \text { LN877618 } & \text { Buxus acuminata } & \end{array}$

